Article

\title{
Design and Synthesis of Arylpiperazine Serotonergic/ Dopaminergic Ligands with Neuroprotective Properties
}

\author{
Margherita Mastromarino ${ }^{1}$, Mauro Niso ${ }^{1}$, Carmen Abate ${ }^{1}\left(0\right.$, Ewgenij Proschak ${ }^{2}$, Mariam Dubiel ${ }^{3}$,

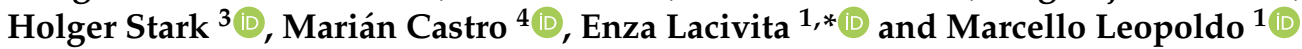

1 Dipartimento di Farmacia-Scienze del Farmaco, Università degli Studi di Bari Aldo Moro, Via Orabona 4, 70125 Bari, Italy; margherita.mastromarino@uniba.it (M.M.); mauro.niso@uniba.it (M.N.); carmen.abate@uniba.it (C.A.); marcello.leopoldo@uniba.it (M.L.)

2 Institute of Pharmaceutical Chemistry, Goethe-University, Max-von-Laue-Str. 9, 60438 Frankfurt am Main, Germany; proschak@pharmchem.uni-frankfurt.de

3 Institute of Pharmaceutical and Medicinal Chemistry, Heinrich Heine University Düsseldorf, Universitaetsstrasse 1, 40225 Duesseldorf, Germany; mariam.dubiel@hhu.de (M.D.); stark@hhu.de (H.S.)

4 Center for Research in Molecular Medicine and Chronic Diseases (CIMUS), Universidade de Santiago de Compostela, Avda de Barcelona s/n, 15782 Santiago de Compostela, Spain; marian.castro@usc.es

* Correspondence: enza.lacivita@uniba.it; Tel.: +39-080-5442750

check for

updates

Citation: Mastromarino, M.; Niso,

M.; Abate, C.; Proschak, E.; Dubiel, M.; Stark, H.; Castro, M.; Lacivita, E.; Leopoldo, M. Design and Synthesis of Arylpiperazine Serotonergic/ Dopaminergic Ligands with Neuroprotective Properties. Molecules 2022, 27, 1297. https://doi.org/ 10.3390/molecules27041297

Academic Editor: Simona Rapposelli

Received: 15 December 2021

Accepted: 10 February 2022

Published: 15 February 2022

Publisher's Note: MDPI stays neutral with regard to jurisdictional claims in published maps and institutional affiliations.

Copyright: (C) 2022 by the authors. Licensee MDPI, Basel, Switzerland. This article is an open access article distributed under the terms and conditions of the Creative Commons Attribution (CC BY) license (https:// creativecommons.org/licenses/by/ $4.0 /)$.

\begin{abstract}
Long-chain arylpiperazine scaffold is a versatile template to design central nervous system (CNS) drugs that target serotonin and dopamine receptors. Here we describe the synthesis and biological evaluation of ten new arylpiperazine derivatives designed to obtain an affinity profile at serotonin $5-\mathrm{HT}_{1 \mathrm{~A}}, 5-\mathrm{HT}_{2 \mathrm{~A}}, 5-\mathrm{HT}_{7}$ receptor, and dopamine $\mathrm{D}_{2}$ receptor of prospective drugs to treat the core symptoms of autism spectrum disorder (ASD) or psychosis. Besides the structural features required for affinity at the target receptors, the new compounds incorporated structural fragments with antioxidant properties to counteract oxidative stress connected with ASD and psychosis. All the new compounds showed CNS MultiParameter Optimization score predictive of desirable ADMET properties and cross the blood-brain barrier. We identified compound 12a that combines an affinity profile compatible with antipsychotic activity $\left(5-\mathrm{HT}_{1 \mathrm{~A}} K_{\mathrm{i}}=41.5 \mathrm{nM}, 5-\mathrm{HT}_{2 \mathrm{~A}} K_{\mathrm{i}}=315 \mathrm{nM}, 5-\mathrm{HT}_{7}\right.$ $K_{\mathrm{i}}=42.5 \mathrm{nM}, \mathrm{D}_{2} K_{\mathrm{i}}=300 \mathrm{nM}$ ), and compound $9 \mathrm{~b}$ that has an affinity profile consistent with studies in the context of ASD (5- $\mathrm{HT}_{1 \mathrm{~A}} K_{\mathrm{i}}=23.9 \mathrm{nM}, 5-\mathrm{HT}_{2 \mathrm{~A}} K_{\mathrm{i}}=39.4 \mathrm{nM}, 5-\mathrm{HT}_{7} K_{\mathrm{i}}=45.0 \mathrm{nM}$ ). Both compounds also had antioxidant properties. All compounds showed low in vitro metabolic stability, the only exception being compound $\mathbf{9 b}$, which might be suitable for studies in vivo.
\end{abstract}

Keywords: serotonin; dopamine; $5-\mathrm{HT}_{1 \mathrm{~A}} ; 5-\mathrm{HT}_{2 \mathrm{~A}} ; 5-\mathrm{HT}_{7} ; \mathrm{D}_{2}$; oxidative stress; arylpiperazine

\section{Introduction}

The long-chain arylpiperazine structure is a versatile model that has allowed the identification of several drugs over the years, such as antipsychotics (aripiprazole, ziprasidone, and lurasidone) [1], anxiolytics (buspirone, tandospirone) [2], and antiparkinsonian drugs (piribedil) [3] (Figure 1). This variety of actions is due to the possibility of modulating the pharmacological profile of the arylpiperazine derivatives through structural variations. Even if more than 30 years have passed since the introduction of buspirone in the market, the long-chain arylpiperazine model is still valid, so that, in the last five years, new drugs with this structure have been introduced on the market [4].

The above-mentioned drugs owe their action to the modulation at the central nervous system (CNS) level of one or more serotonin and/or dopamine receptors that are relevant to the specific pathology. For example, aripiprazole owes its antipsychotic action to the blocking of dopaminergic $\mathrm{D}_{2}$ and serotonergic $5-\mathrm{HT}_{2 \mathrm{~A}}$ receptors. The anxiolytic action of buspirone is due to a partial agonist activity on the 5- $\mathrm{HT}_{1 \mathrm{~A}}$ receptors, while the antiparkinsonian effect of piribedil is due to dopaminergic $D_{2}$ receptors activation. 
Recently, we reported on a set of arylpiperazine derivatives with an activity profile on a subgroup of serotonin receptors $\left(5-\mathrm{HT}_{7}\right.$ and $5-\mathrm{HT}_{1 \mathrm{~A}}$ agonist and $5-\mathrm{HT}_{2 \mathrm{~A}}$ antagonist) specifically designed to obtain prospective drugs for the treatment of the core symptoms of autism spectrum disorder [5]. Over the last few years, several studies have highlighted that besides an adequate modulation of the neuroreceptors relevant in the pathology, a neuroprotective action due to a reduction of oxidative stress might have a beneficial effect on these pathologies. In fact, schizophrenia, depression, and autism spectrum disorder (ASD) have a significant neuroinflammatory component linked to oxidative stress [6]. Therefore, the advantage of intervening in targeting a set of receptors and oxidative stress is evident. Of note, recent studies have shown that the activation of the 5-HT $\mathrm{HT}_{1 \mathrm{~A}}$ [7] and $5-\mathrm{HT}_{7}$ receptors [8] produces neuroprotective effects. Thus, for the present study, we have designed a set of new arylpiperazine derivatives with the structural characteristics to target a group of neuroreceptors relevant to treating schizophrenia or ASD and producing neuroprotective effects.<smiles>O=C1CCc2ccc(OCCCCN3CCN(c4cccc(Cl)c4Cl)CC3)cc2NC1=O</smiles><smiles>c1cnc(N2CCN(Cc3ccc4c(c3)OCO4)CC2)nc1</smiles><smiles>COc1ccc(-c2ccccc2N2CCN(CCCCOc3ccc4c(C)cc(=O)oc4c3)CC2)cc1</smiles>

Figure 1. Representative arylpiperazine derivatives.

\section{Results}

\subsection{Study Design}

The starting point for our study was AG-45 (compound 20b in Ref. [5], Figure 1), which has an affinity for $5-\mathrm{HT}_{1 \mathrm{~A}}, 5-\mathrm{HT}_{2 \mathrm{~A}}$, and $5-\mathrm{HT}_{7}$ receptors. We specifically searched this affinity profile to obtain prospective drugs for the treatment of the core symptoms of ASD. Thus, we introduced structural fragments known for their antioxidant properties, such as the pyridyl [9], 1,2,4-triazine [10], 1,4-benzoxazine [11], and benzopyrone [12], and left unchanged the features responsible for the affinity profile (i.e., the biphenyl-like structure linked to the piperazine ring, and a trimethylene or tetramethylene spacer between the piperazine ring and the terminal fragment). The design of the target compounds is graphically illustrated in Figure 2. Interestingly, AG-45 showed a measurable affinity for the $\mathrm{D}_{2}$ receptor, and this prompted us to evaluate structural modifications to increase $\mathrm{D}_{2}$ receptor affinity in the prospect of obtaining antipsychotic compounds with antioxidant properties. Of note, while the affinity for $\mathrm{D}_{2}$ and $5-\mathrm{HT}_{2 \mathrm{~A}}$ receptors is a crucial feature of atypical antipsychotics, targeting $5-\mathrm{HT}_{1 \mathrm{~A}}$ and $5-\mathrm{HT}_{7}$ receptors have been variously correlated to beneficial effects in the context of psychosis $[13,14]$.

The discovery of CNS drugs also faces the challenge of controlling physicochemical properties. CNS Multi-Parameter Optimisation (MPO) scoring tool is an approach that can facilitate the design of CNS drugs [15]. This tool gives a desirability score (0.05-1) for six physicochemical properties: molecular weight (MW); calculated partition coefficient $(\operatorname{cLog} P)$; calculated distribution coefficient at $\mathrm{pH}=7.4\left(\operatorname{cLog} D_{7.4}\right)$; acid dissociation constant 
$\left(\mathrm{pK}_{\mathrm{a}}\right)$; topological polar surface area (TPSA); number of hydrogen bond donors (HBD). The sum of these scores yields the CNS MPO score on a 0.3-6 scale. A CNS MPO desirability score higher than 4 is predictive of desirable ADMET properties and cross the blood-brain barrier [15]. As shown in Table 1, all the newly designed compounds display favorable characteristics for a prospective CNS drug.

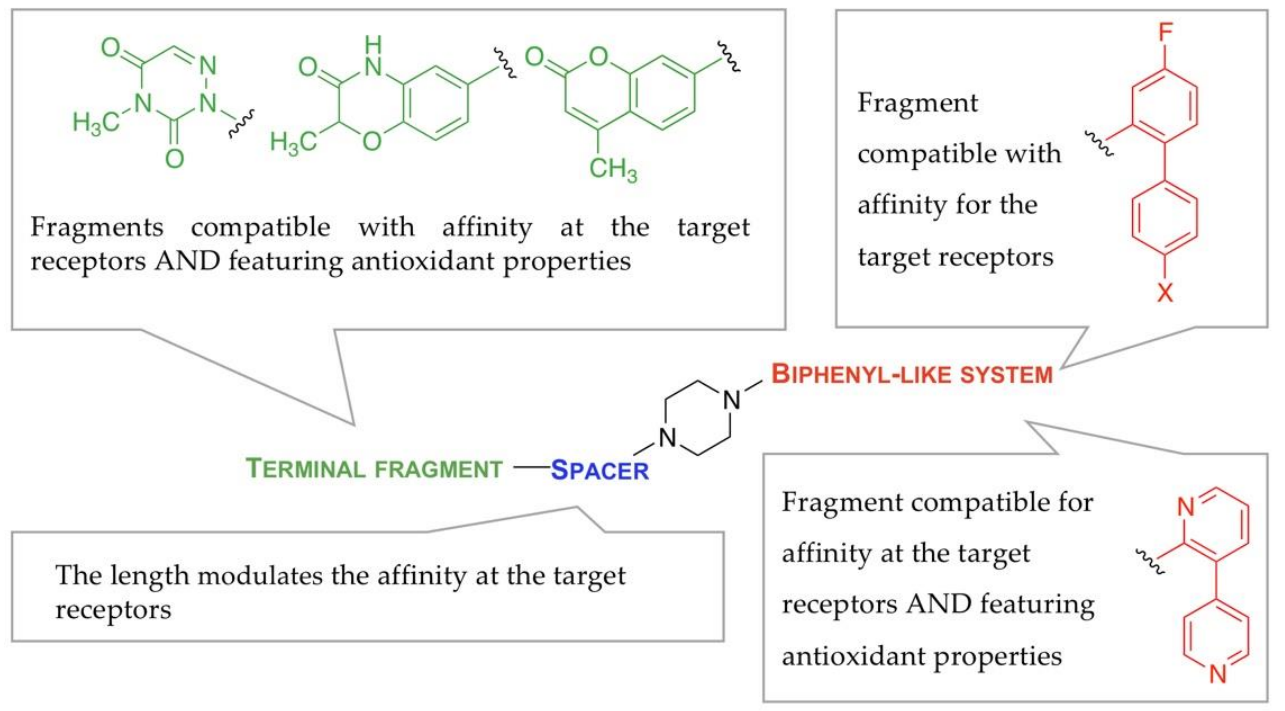

Figure 2. Design Strategy for the Target Compounds.

Table 1. Lipophilicity (cLogP), CNS MPO, and Metabolic Stability (MS) of the Target Compounds.

\begin{tabular}{|c|c|c|c|c|c|}
\hline Compc & & Structure & $c \log P 1$ & $\mathrm{MPO}^{2}$ & $\mathrm{MS}^{3}$ \\
\hline $8 a$ & $\mathrm{n}=3$ & & 2.79 & 4.98 & $4 \%$ \\
\hline $8 b$ & $\mathrm{n}=4$ & & 3.31 & 4.54 & $14 \%$ \\
\hline $9 a$ & $\mathrm{n}=3$ & & 3.06 & 5.05 & $<3 \%$ \\
\hline $9 b$ & $\mathrm{n}=4$ & & 3.58 & 4.47 & $45 \%$ \\
\hline $10 a$ & $\mathrm{n}=3$ & & 3.08 & 5.07 & $5 \%$ \\
\hline $10 \mathrm{~b}$ & $\mathrm{n}=4$ & & 3.60 & 4.49 & $26 \%$ \\
\hline 11a & $\mathrm{n}=3$ & & 1.24 & 5.66 & $4 \%$ \\
\hline $11 b$ & $\mathrm{n}=4$ & & 1.76 & 5.44 & $3 \%$ \\
\hline $12 a$ & $\mathrm{n}=3$ & & 3.55 & 4.52 & $19 \%$ \\
\hline $12 b$ & $\mathrm{n}=4$ & $\mathrm{H}$ & 4.07 & 3.97 & $14 \%$ \\
\hline
\end{tabular}

${ }_{1}$ cLogP values were calculated with ChemAxon software; ${ }^{2}$ Multi-Parameter Optimisation; ${ }^{3}$ Metabolic Stability (percentage of recovery of the parent compound after incubation for $30 \mathrm{~min}$ with rat microsomes).

\subsection{Chemistry}

The synthesis of the target compounds $\mathbf{8} \mathbf{a}, \mathbf{b} \mathbf{- 1 2} \mathbf{1 2}, \mathbf{b}$ was accomplished through the reaction of the appropriate chloroalkyl derivatives $\mathbf{2} \mathbf{a}, \mathbf{b}-\mathbf{4} \mathbf{a} \mathbf{a}, \mathbf{b}$ with arylpiperazines $5-7$ 
(Scheme 1). Both chloroalkyl and arylpiperazine intermediates were synthesized with literature methods (as detailed in the Materials and Methods) except alkyl chloride $\mathbf{2 b}$ which was prepared by alkylating 6-hydroxy-2-methyl-2H-benzo[b][1,4]oxazin-3(4H)-one (1) [16] with 1-bromo-4-chlorobutane via the Williamson's synthesis under basic conditions.<smiles>CC(C)C[R8]1ccccc1</smiles><smiles>[X]c1ccc(-c2cc(F)ccc2N2CCNCC2)cc1</smiles><smiles>[Y]C(C)C</smiles>

$9 \mathbf{a}(\mathrm{n}=3)$

$9 b(n=4)$

$10 \mathrm{a}(\mathrm{n}=3)$

$10 b(n=4)$<smiles>c1cnc(N2CCNCC2)c(-c2ccncc2)c1</smiles>

7

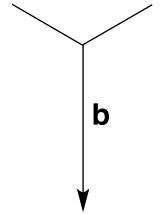

$11 a(n=3)$

$11 b(n=4)$<smiles>Cc1cc(=O)oc2cc(O[Ga]Cl)ccc12</smiles>

$4 a(n=3)$

b

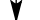

$12 \mathrm{a}(\mathrm{n}=3)$

12b $(\mathrm{n}=4)$

Scheme 1. Reagents and conditions: (a) 1-bromo-3-chloropropane or 1-bromo-4-chlorobutane, NaH, anhydrous DMF, r.t., 12 h; (b) $\mathrm{Na}_{2} \mathrm{CO}_{3}$, acetonitrile, reflux, overnight.

\subsection{Radioligand Binding Experiments}

The final compounds were tested for their affinity at serotonin $5-\mathrm{HT}_{1 \mathrm{~A}}, 5-\mathrm{HT}_{2 \mathrm{~A}}$, and $5-\mathrm{HT}_{7}$ receptors and at dopamine $\mathrm{D}_{1}, \mathrm{D}_{2}, \mathrm{D}_{3}$, and $\mathrm{D}_{5}$ receptors. As a first step, competition radioligand binding assays were carried out for all the compounds at the single concentration of $10 \mu \mathrm{M}$, on membrane preparations from stable cell lines heterologously expressing the human cloned $5-\mathrm{HT}_{1 \mathrm{~A}}, 5-\mathrm{HT}_{2 \mathrm{~A}}$, or $5-\mathrm{HT}_{7}$ receptors. Affinity was determined for those compounds showing \% of displacement of the specific binding of the radioligand over $65 \%$ at $10 \mu \mathrm{M}$ concentration, by means of competition binding curves of six concentration datapoints (typically from $0.1 \mathrm{nM} / 1 \mathrm{nM}$ to $10 \mu \mathrm{M} / 100 \mu \mathrm{M}$ ). The affinity of the compounds, expressed as equilibrium dissociation constant $\left(K_{\mathrm{i}}\right)$ value, is shown in Table 2. For the affinity determination at dopamine receptor subtypes, membrane fractions of human dopamine $\mathrm{D}_{2 \mathrm{~s}}, \mathrm{D}_{3}, \mathrm{D}_{1}$, and $\mathrm{D}_{5}$ receptor-expressing cells were used. They were co-incubated with $\left[{ }^{3} \mathrm{H}\right]$ spiperone (for $\mathrm{D}_{2 \mathrm{~s}}$ and $\mathrm{D}_{3}$ receptor) or $\left[{ }^{3} \mathrm{H}\right] \mathrm{SCH} 23390$ (for $\mathrm{D}_{1}$ and $\mathrm{D}_{5}$ receptor) and appropriate concentrations of test compound for $120 \mathrm{~min}$. Bound radioligand was separated from the free ligand using filtration. Radioactivity was measured by liquid scintillation counting. The resulting $K_{\mathrm{i}}$ values with $95 \%$ confidence intervals are listed in Table 2. 
Table 2. Affinity and Cytotoxicity Data of the Target Compounds.

\begin{tabular}{|c|c|c|c|c|c|c|c|c|}
\hline \multirow[t]{3}{*}{ Compd } & \multicolumn{7}{|c|}{ Affinity } & \multirow{3}{*}{$\begin{array}{c}\text { Cytotoxicity } \\
\mathrm{EC}_{50}[\mu \mathrm{M}] \pm \text { S.E.M }\end{array}$} \\
\hline & \multicolumn{3}{|c|}{$K_{\mathrm{i}}[\mathrm{nM}] \pm$ S.E.M. } & \multicolumn{4}{|c|}{$K_{\mathrm{i}}[\mathrm{nM}](\mathrm{CI}$ 95\%) } & \\
\hline & $5-\mathrm{HT}_{1 \mathrm{~A}} 1$ & $5-\mathrm{HT}_{2 \mathrm{~A}}{ }^{1}$ & $5-\mathrm{HT}_{7}{ }^{1}$ & $\mathrm{D}_{2}$ & $\mathrm{D}_{3}$ & $\mathrm{D}_{1}$ & $\mathrm{D}_{5}$ & \\
\hline $8 \mathbf{a}$ & $13.1 \pm 2.3$ & $782 \pm 119$ & $10.7 \pm 0.7$ & $\begin{array}{c}388 \\
(249 ; 606)\end{array}$ & $\begin{array}{c}1223 \\
(684 ; 2185)\end{array}$ & $\begin{array}{c}6290 \\
(1608 ; 24,595) \\
\end{array}$ & $\begin{array}{c}7412 \\
(2038 ; 26,956)\end{array}$ & $32.9 \pm 3.5$ \\
\hline $8 b$ & $17.6 \pm 0.9$ & $611 \pm 87$ & $9.38 \pm 0.42$ & $\begin{array}{c}9.08 \\
(5.07 ; 16.2)\end{array}$ & $\begin{array}{c}691 \\
(516 ; 926)\end{array}$ & $\begin{array}{c}1711 \\
(981 ; 2983)\end{array}$ & $\begin{array}{c}8205 \\
(2475 ; 27,203)\end{array}$ & $25.5 \pm 2.2$ \\
\hline $9 a$ & $653 \pm 95$ & $49.1 \pm 12$ & $60.8 \pm 7.1$ & $>10,000$ & $>10,000$ & $\begin{array}{c}193 \\
(137 ; 271)\end{array}$ & $\begin{array}{c}413 \\
(199 ; 856)\end{array}$ & nd \\
\hline $9 b$ & $23.9 \pm 4.9$ & $39.4 \pm 7.4$ & $45.0 \pm 3.4$ & $>10,000$ & $>10,000$ & $\begin{array}{c}88.3 \\
(35.7 ; 218) \\
\end{array}$ & $\begin{array}{c}222 \\
(76.0 ; 646)\end{array}$ & $51.9 \pm 4.3$ \\
\hline $10 \mathrm{a}$ & $1091 \pm 154$ & $96.8 \pm 11$ & $45.7 \pm 1.3$ & $>10,000$ & $>10,000$ & $\begin{array}{c}104 \\
(33.0 ; 331)\end{array}$ & $\begin{array}{c}180 \\
(96.2 ; 338)\end{array}$ & $28.2 \pm 3.2$ \\
\hline $10 \mathrm{~b}$ & $43.4 \pm 6.2$ & $80.7 \pm 3.1$ & $36.5 \pm 5.2$ & $>10,000$ & $>10,000$ & $\begin{array}{c}140 \\
(73.4 ; 268)\end{array}$ & $\begin{array}{c}101 \\
(33.8 ; 299)\end{array}$ & $34.3 \pm 2.5$ \\
\hline $11 \mathrm{a}$ & $269 \pm 18$ & $>10,000$ & $44.5 \pm 2.2$ & $>10,000$ & $>10,000$ & $>10,000$ & $>10,000$ & $>100$ \\
\hline $11 b$ & $5.19 \pm 0.12$ & $>10,000$ & $79.4 \pm 9.0$ & $>10,000$ & $>10,000$ & $>10,000$ & $>10,000$ & $>100$ \\
\hline $12 a$ & $41.5 \pm 3.0$ & $315 \pm 44$ & $42.5 \pm 6.2$ & $\begin{array}{c}300 \\
(210 ; 430) \\
\end{array}$ & $\begin{array}{c}1075 \\
(651 ; 1776) \\
\end{array}$ & $\begin{array}{c}2198 \\
(780 ; 6191)\end{array}$ & $>10,000$ & $35.2 \pm 4.1$ \\
\hline $12 b$ & $11.3 \pm 0.4$ & $\sim 1419^{2}$ & $52.2 \pm 10.6$ & $\begin{array}{c}17.0 \\
(4.56 ; 63.5)\end{array}$ & $\begin{array}{c}424 \\
(201 ; 960)\end{array}$ & $\begin{array}{c}1527 \\
(354 ; 6586)\end{array}$ & $\begin{array}{c}2733 \\
(683 ; 10,929)\end{array}$ & $47.9 \pm 3.5$ \\
\hline
\end{tabular}

${ }^{1}$ Average data from $\mathrm{n}=3$ independent experiments performed in duplicate. ${ }^{2}$ Full displacement of specific binding not achieved at the maximum concentration assayed $(100 \mu \mathrm{M})$, so $K_{\mathrm{i}}$ value might not be accurately estimated; maximum displacement achieved was $84 \%$ ).

\subsection{Docking Studies}

Docking studies were performed to rationalize the different binding profiles of the compounds. Representative compounds were docked at the serotonin 5- $\mathrm{HT}_{1 \mathrm{~A}}$ and 5$\mathrm{HT}_{2 \mathrm{~A}}$, and dopamine $\mathrm{D}_{2}$ and $\mathrm{D} 1 \mathrm{using}$ the available crystal structures of the receptors (Figures 3 and 4).

a)

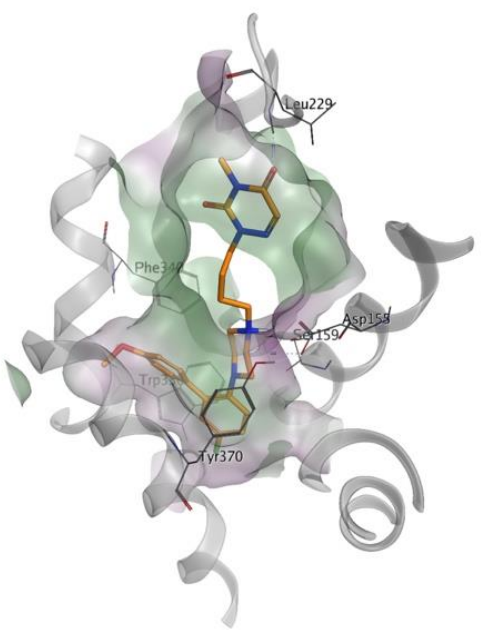

b)

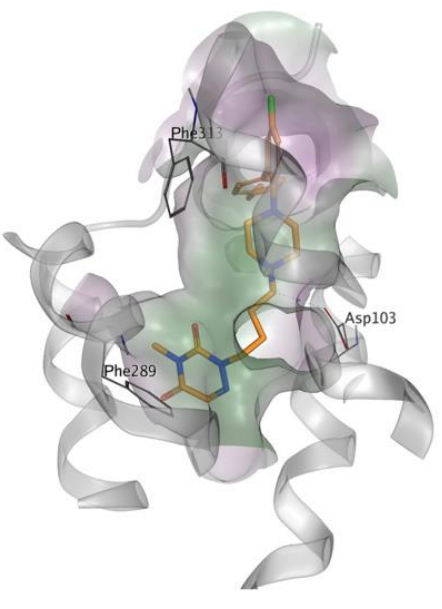

c)

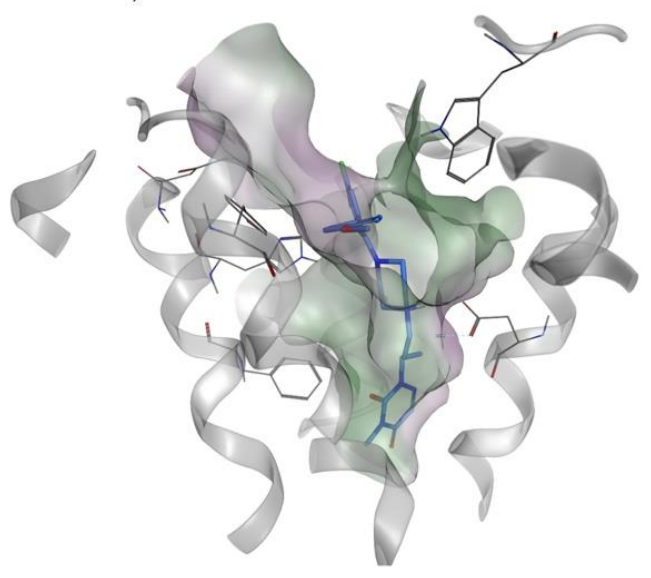

Figure 3. Docking poses of compound $\mathbf{9 b}$ at (a) serotonin $5-\mathrm{HT}_{2 \mathrm{~A}}$ receptor; (b) dopamine $\mathrm{D}_{1}$ receptor; (c) dopamine $\mathrm{D}_{2}$ receptor. 
a)

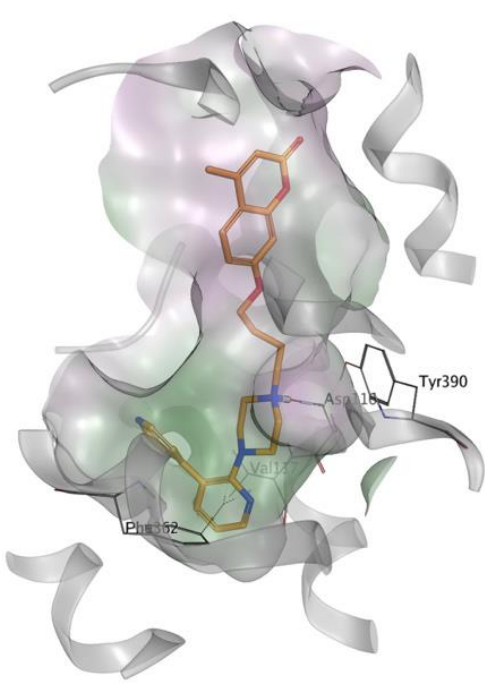

b)

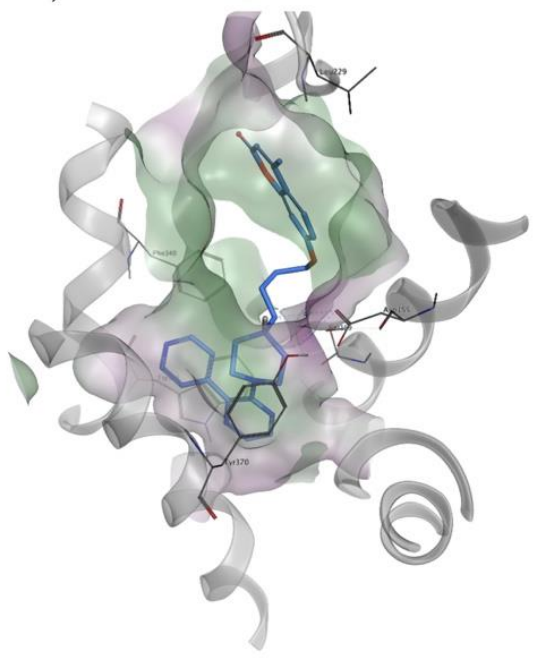

c)

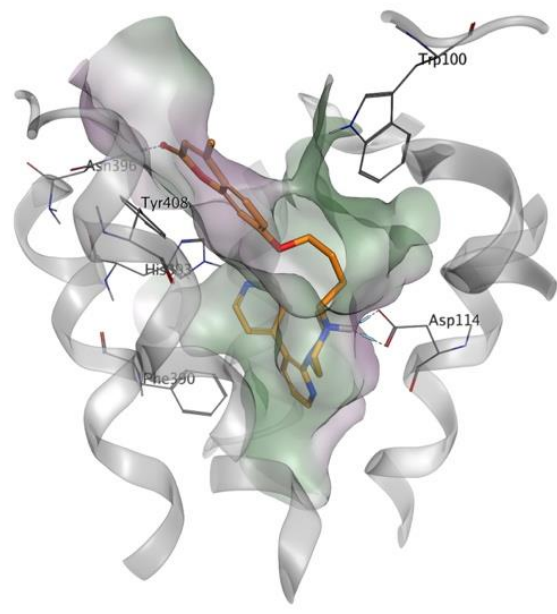

Figure 4. Docking poses of compound $\mathbf{1 2 b}$ at (a) serotonin $5-\mathrm{HT}_{1 \mathrm{~A}}$ receptor; $(\mathbf{b})$ serotonin $5-\mathrm{HT}_{2 \mathrm{~A}}$ receptor; $(\mathbf{c})$ dopamine $\mathrm{D}_{2}$ receptor.

\subsection{In Vitro Metabolic Stability}

To evaluate the susceptibility to first-pass oxidative metabolism, the leading cause of metabolic degradation in vivo [17] the target compounds were incubated with rat liver microsomes. The turnover of the parent compound was assessed as the percentage of the parent compound recovered after $30 \mathrm{~min}$ of incubation with microsomes in the presence of an NADPH-regenerating system [18]. The percentages of the recovered unchanged parent compound are listed in Table 1.

\subsection{Neuroprotection against $\mathrm{H}_{2} \mathrm{O}_{2}$ in SHSY-5Y Cell Line}

Initially, the cytotoxicity of the target compounds was assessed by treating SH-SY5Y cells for $48 \mathrm{~h}$ with various concentrations of compounds $(0.1$ to $100 \mu \mathrm{M})$. Compounds $11 \mathrm{a}$ and 11b were not cytotoxic at the tested doses, while the remaining were cytotoxic, exhibiting $\mathrm{EC}_{50}$ values between $20-50 \mu \mathrm{M}$ (Table 2). Cells treatment with $1 \mu \mathrm{M}$ or $5 \mu \mathrm{M}$ of each compound for $24 \mathrm{~h}$ did not result in an effect on cell viability $(<4 \%$ and $<8 \%$ decrease at a concentration of $1 \mu \mathrm{M}$ and $5 \mu \mathrm{M}$, respectively).

Treatment of SH-SY5Y cells with $400 \mu \mathrm{M} \mathrm{H}_{2} \mathrm{O}_{2}$ for $24 \mathrm{~h}$ led to a reduction of cell viability of $72-76 \%$ (Figure 3 ). The protective effect of each compound was determined by pretreating the cells with the test compound for $3 \mathrm{~h}$ at the non-toxic doses of $1 \mu \mathrm{M}$ and $5 \mu \mathrm{M}$, and subsequent treatment with $400 \mu \mathrm{M} \mathrm{H}_{2} \mathrm{O}_{2}$ for an additional $24 \mathrm{~h}$. Pre-treatment of SH-SY5Y cells with compounds $8 \mathbf{a}, \mathbf{b}, \mathbf{9 b}, \mathbf{1 0 a}, \mathbf{1 1 a}$, and $\mathbf{1 2}$ a resulted in a $14-20 \%$ recovery of cell viability with respect to treatment with the $\mathrm{H}_{2} \mathrm{O}_{2}$ alone (Figure 5). 


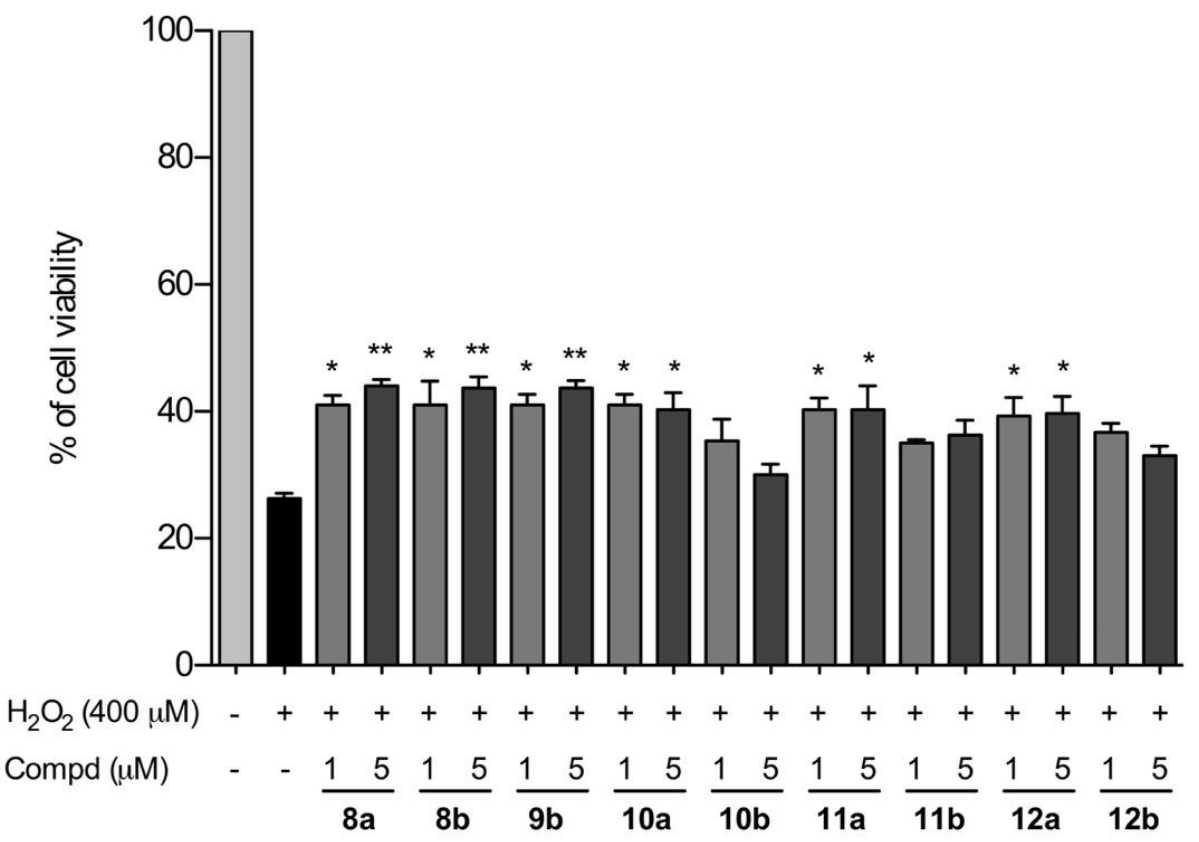

Figure 5. Cell viability of SH-SY5Y cells pretreated with $1 \mu \mathrm{M}$ or $5 \mu \mathrm{M}$ of the test compound for $3 \mathrm{~h}$, and subsequently exposed to $400 \mu \mathrm{M} \mathrm{H}_{2} \mathrm{O}_{2}$ for $24 \mathrm{~h}$. The data are shown as the mean \pm S.E.M. of three independent experiments (** $p<0.001 * p<0.05$ vs. $400 \mu \mathrm{M} \mathrm{H}_{2} \mathrm{O}_{2}$-treated group).

\section{Discussion}

The binding affinities of the target compounds are listed in Table 2. The analysis of the binding data at the screened receptors provides information regarding the role of the three structural elements that compose the structure, i.e., biphenyl-like system, spacer, and terminal fragment.

Considering the affinities for the $5-\mathrm{HT}_{1 \mathrm{~A}}$ receptor, we can note that both biphenyl-like systems and terminal fragments selected for the study are compatible with high affinity at the receptor. In fact, four compounds out of 10 show $K_{\mathrm{i}}$ values lower than $17.6 \mathrm{nM}$ (compounds $\mathbf{8 a}, \mathbf{b}, \mathbf{1 1} \mathbf{b}, \mathbf{1 2} \mathbf{b}$ ). The differences in affinity are related to the length of the spacer between the piperazine and the terminal fragment. Examining the compounds characterized by the oxotriazinyl terminal fragment (compounds $\mathbf{9 a , b - 1 1 a , b}$ ), the derivatives with a tetramethylene spacer have higher affinity than the trimethylene counterparts. The influence of the spacer length on affinity is related to the nature of the terminal fragment. In fact, considering the compounds featuring the bipyridyl system linked to the piperazine, the $K_{\mathrm{i}}$ ratios of the trimethylene and tetramethylene homologs are variable $(\mathbf{1 1} \mathbf{a} / \mathbf{1 1} \mathbf{b}=52$; $\mathbf{1 2 a} / \mathbf{1 2 b}=3.7 ; \mathbf{8 a} / \mathbf{8 b}=0.7$ ).

As for the $5-\mathrm{HT}_{2 \mathrm{~A}}$ receptor, the compounds featuring the bipyridyl system linked to the piperazine display moderate to low affinity. Within this group of compounds, the terminal fragment plays a role on affinity. In fact, the compounds with the oxotriazinyl fragment have a low affinity, whereas a bicyclic terminal fragment imparts comparatively higher affinity. The replacement of the bipyridyl with a biphenyl system has a favorable effect on the affinity. In fact, for the compounds with a tetramethylene spacer, $9 \mathbf{b}$ has a slightly higher affinity than $\mathbf{1 0 b}$ which shows much higher affinity than $\mathbf{1 1 b}$. A similar trend can be observed for the trimethylene spacer derivatives 9a, 10a, and 11a.

The affinity values of the target compounds at $5-\mathrm{HT}_{7}$ receptor are distributed in a narrower range as compared to the other receptors under study. In fact, the highest affinity values were shown by $\mathbf{8 b}\left(K_{\mathrm{i}}=9.38 \mathrm{nM}\right)$ and the lowest by $\mathbf{1 1 b}\left(K_{\mathrm{i}}=79.4 \mathrm{nM}\right)$. Consequently, the differences in affinity between homologs (trimethylene or tetramethylene spacer derivatives) or analogs (i.e., pair of compounds featuring the same biphenyl-like system and a different terminal fragment) are always lower than 2 -fold. 
As for the $D_{2}$-like receptors $\left(D_{2}\right.$ and $\left.D_{3}\right)$, it is immediately evident that the oxotriazinyl terminal fragment leads to compounds devoid of affinity (compounds $\mathbf{9 a}, \mathbf{b}-\mathbf{1 1 a}, \mathbf{b}$ ). By contrast, the bicyclic terminal fragments lead from moderate to high affinity (compounds $\mathbf{8} \mathbf{a}, \mathbf{b}, \mathbf{1 2} \mathbf{a}, \mathbf{b})$ to both $\mathrm{D}_{2}$ and $\mathrm{D}_{3}$ receptors, being the affinity for the former receptor slightly higher. For these compounds, the tetramethylene derivatives have slightly higher affinity than the trimethylene analogs.

Regarding the $\mathrm{D}_{1}$-like receptors $\left(\mathrm{D}_{1}\right.$ and $\left.\mathrm{D}_{5}\right)$, the biphenyl-like system influences the affinity to a greater extent than the terminal fragment. In fact, the bipyridyl fragment leads to low affinity for $D_{1}$ and $D_{5}$ receptors, whereas the biphenyl fragment to moderate affinity. Considering compounds $\mathbf{9 a}, \mathbf{b}$ and $\mathbf{1 0 a}, \mathbf{b}$, the trimethylene or tetramethylene homologs display a difference in affinity lower than 2-fold.

Collectively, the binding data of the target compounds revealed that the three structural elements that compose the structure have different effects on the affinity for the receptors under study. For 5- $\mathrm{HT}_{1 \mathrm{~A}}$ receptor, variations of length of the spacer result in the highest variations in affinity. For $5-\mathrm{HT}_{2 \mathrm{~A}}$ receptors, the nature of the biphenyl-like system has high influence on the affinity. For $5-\mathrm{HT}_{7}$ receptor, the biphenyl-like systems linked to the piperazine ring confirmed their favorable role on affinity, with no substantial effects of both the spacer length and the terminal fragments. For $\mathrm{D}_{2}$-like receptor, the terminal fragment has a pronounced impact on affinity, whereas for $\mathrm{D}_{1}$-like receptor biphenyl-like system has a greater effect.

To identify molecular contacts responsible for the observed affinity profile, compounds $9 b$ and $12 b$ were docked at serotonin $5-\mathrm{HT}_{1 \mathrm{~A}}$ and $5-\mathrm{HT}_{2 \mathrm{~A}}$ and dopamine $\mathrm{D}_{2}$ and $\mathrm{D}_{1}$ receptors. We found that compounds orientations were analogous for all the studied receptors, except for the dopamine $\mathrm{D}_{1}$ receptor, with the piperazine moiety forming a strong charged-assisted hydrogen bond with the highly conserved aspartate residue on the third transmembrane helix and the aryl substituent linked to the piperazine ring deeply buried in the binding site. By comparing the docking poses at serotonin $5-\mathrm{HT}_{2 \mathrm{~A}}$ receptor of compounds $\mathbf{9 b}\left(5-\mathrm{HT}_{2 \mathrm{~A}} K_{\mathrm{i}}=39.4 \mathrm{nM}\right)$ and $\mathbf{1 2 b}\left(5-\mathrm{HT}_{2 \mathrm{~A}} K_{\mathrm{i}}=1492 \mathrm{nM}\right)$, it is evident that the dimension of the terminal fragment impacts the interaction of the molecule with the receptor. In fact, the oxotriazinyl terminal fragment of compound $\mathbf{9 b}$ formed an additional contact with Leu229 of ECL2. In contrast, the bicyclic terminal fragment of compound 12b is too big to allow a proper accommodation in the binding pocket and leads to a steric clash. Similarly, compounds $\mathbf{9 b}$ and $\mathbf{1 2 b}$ showed very different binding poses at the dopamine $\mathrm{D}_{2}$ receptor, which agree with the very different $K_{\mathrm{i}}$ values (compound $\mathbf{9 b} K_{\mathrm{i}}=>10,000 \mathrm{nM}$, compound $\mathbf{1 2 b} K_{\mathrm{i}}=17.0 \mathrm{nM}$ ). In fact, while the arylpiperazine moiety of compound $\mathbf{1 2 b}$ is located deeper into the binding site and the terminal fragment is orientated towards the extracellular milieu forming an additional contact with Asn396, compound 9b showed an opposite orientation with the arylpiperazine pointing towards the extracellular milieu that is not in agreement with the observed structure-activity relationships.

Binding affinity data and docking poses indicated that, when the structural requirements for high affinity for a given set of receptors overlap, compounds with different profiles can be identified. In fact, compounds $9 \mathrm{~b}$ and $\mathbf{1 0 b}$ have a balanced profile concerning the affinity for $5-\mathrm{HT}_{1 \mathrm{~A}}, 5-\mathrm{HT}_{2} \mathrm{~A}$, and $5-\mathrm{HT}_{7}$ receptors, which is the desired affinity profile to obtain prospective drugs for the treatment of the core symptoms of ASD. In addition, the selectivity over $\mathrm{D}_{2}$ receptors of both $\mathbf{9 b}$ and $\mathbf{1 0 b}$ is indeed favorable in terms of potential extrapyramidal side effects. On the other hand, compounds $\mathbf{8 b}$ and $\mathbf{1 2} \mathbf{a}$ have an affinity profile compatible with antipsychotic activity, as they have an affinity for the $D_{2}$ receptor, being 12a preferable for the balanced affinity for $D_{2}$ and 5- $\mathrm{HT}_{2} \mathrm{~A}$ receptors, accompanied by a comparable affinity for $5-\mathrm{HT}_{1 \mathrm{~A}}$ and $5-\mathrm{HT}_{7}$ receptors.

Next, we studied the potential of the target compounds to protect against apoptosis induced by $\mathrm{H}_{2} \mathrm{O}_{2}$ using SH-SY5Y neuroblastoma cells as an experimental model.

We first evaluated the cytotoxicity of the target compounds alone and found that compounds $11 \mathrm{a}$ and $\mathbf{1 1 b}$ were not cytotoxic in the dose range of 0.1 to $100 \mu \mathrm{M}$, while the remaining compounds showed moderate cytotoxicity, having $\mathrm{EC}_{50}$ values between 
20-50 $\mu \mathrm{M}$ (Table 2). Of note, SH-SY5Y cells treatment with each compound at $1 \mu \mathrm{M}$ or $5 \mu \mathrm{M}$ concentration for $24 \mathrm{~h}$ had a marginal effect on cell viability, with a decrease lower than $4 \%$ or $8 \%$ at $1 \mu \mathrm{M}$ or $5 \mu \mathrm{M}$, respectively.

Next, the protective effect of each compound was determined by pretreating the cells with the test compound for $3 \mathrm{~h}$ at the non-toxic doses of $1 \mu \mathrm{M}$ and $5 \mu \mathrm{M}$, and subsequent treatment with $400 \mu \mathrm{M} \mathrm{H}_{2} \mathrm{O}_{2}$ for an additional $24 \mathrm{~h}$. Treatment of SH-SY5Y cells with $400 \mu \mathrm{M} \mathrm{H}_{2} \mathrm{O}_{2}$ for $24 \mathrm{~h}$ caused a reduction of cell viability of $72-76 \%$ (Figure 3). Pretreatment of SH-SY5Y cells with compounds $\mathbf{8 a}, \mathbf{b}, \mathbf{9} \mathbf{b}$, and $\mathbf{1 0 a}-\mathbf{1 2} \mathbf{a}$ resulted in a statistically significant recovery of cell viability with respect to treatment with the $400 \mu \mathrm{M} \mathrm{H}_{2} \mathrm{O}_{2}$ alone at both concentrations studied (Figure 3). Thus, compounds $\mathbf{8 b}, \mathbf{9} \mathbf{b}$, and $\mathbf{1 2} \mathbf{a}$ stand out of the set because they combine a favorable affinity profile with antioxidant properties.

The target compounds were screened for their in vitro metabolic stability to evaluate their liability to metabolic degradation by first-pass oxidative metabolism-the main cause of metabolic degradation in vivo [17]. The metabolic stability was assessed as the percentage of the parent compound recovered after $30 \mathrm{~min}$ of incubation with rat microsomes in the presence of an NADPH-regenerating system (Table 1). Compound $\mathbf{9 b}$ was the most stable compound as it showed a percentage of recovery (45\%) that is predictive of low clearance in vivo, based on our previous data on a broad set of analog arylpiperazine derivatives $[5,18]$. Among the remaining compounds, $\mathbf{1 0 b}$ and 12a showed borderline stability value, while the others were massively metabolized. By comparing the cLogP values and metabolic stability of each compound, it emerges that the compound's oxidative liability is not related to lipophilicity, as shown by pairs of compounds $\mathbf{9 a}, \mathbf{b}$ and $\mathbf{1 0 a}, \mathbf{b}$ (Table 1).

Finally, the solubility of compounds $\mathbf{9 b}$ and $\mathbf{1 2 a}$, which showed the best combination of biological activity and metabolic stability, were calculated using the Swiss ADME algorithm [19]. Both compounds were predicted as moderately soluble showing solubility values in the same range of buspirone and aripiprazole (solubility $\mathbf{9 b}$ : $5.08 \times 10^{-3} \mathrm{mg} / \mathrm{mL} ; \mathbf{1 2 a}: 5.06 \times 10^{-3} \mathrm{mg} / \mathrm{mL}$; buspirone: $8.64 \times 10^{-2} \mathrm{mg} / \mathrm{mL}$; aripiprazole: $1.88 \times 10^{-3} \mathrm{mg} / \mathrm{mL}$ ).

\section{Materials and Methods}

\subsection{Chemicals}

Chemicals were purchased from Sigma-Aldrich, Alfa Aesar, TCI Chemicals. Unless otherwise stated, all chemicals were used without further purification. Thin layer chromatography (TLC) was performed using plates from Merck (silica gel 60 F254). Column chromatography was performed with 1:30 Merck silica gel $60 \AA(63-200 \mu \mathrm{m})$ as the stationary phase. Flash chromatographic separations were performed on a Biotage SP1 purification system using flash cartridges pre-packed with KP-Sil $32-63 \mu \mathrm{m}, 60 \AA$ A silica. ${ }^{1} \mathrm{H}$ NMR spectra were recorded on a Varian Mercury-VX spectrometer $(300 \mathrm{MHz})$ or on a 500-vnmrs500 Agilent spectrometer $(500 \mathrm{MHz})$. All chemical shift values are reported in ppm ( $\delta$ ). Recording of mass spectra was done on an HP6890-5973 MSD gas chromatograph/mass spectrometer; only significant $m / z$ peaks, with their percentage of relative intensity in parentheses, are reported. HRMS-ESI analyses were performed on a Bruker Datonics MicrOTOF-Q II mass spectrometer, mass range $50-800 \mathrm{~m} / z$, electrospray ion source in positive or negative ion mode. All spectra were in accordance with the assigned structures. Elemental analyses $(\mathrm{C}, \mathrm{H}, \mathrm{N})$ of the target compounds were performed on a Eurovector Euro EA 3000 analyzer. Analyses indicated by the symbols of the elements were within \pm $0.4 \%$ of the theoretical values. The purity of the target compounds listed in Table 1 was assessed by RP-HPLC and combustion analysis. All compounds showed $\geq 95 \%$ purity. RP-HPLC analysis was performed on an Agilent 1260 Infinity Binary LC System equipped with a diode array detector using a Phenomenex Gemini C-18 column $(250 \mathrm{~mm} \times 4.6 \mathrm{~mm}$, $5 \mu \mathrm{m}$ particle size). All target compounds (Table 1 ) were eluted with $\mathrm{CH}_{3} \mathrm{CN} /$ ammonium

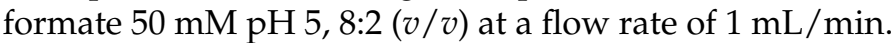


The following compounds were prepared as described in the literature: 6-hydroxy-2-methyl2H-benzo[b][1,4]oxazin-3(4H)-one (1) [20], 6-(3-chloropropoxy)-2-methyl-2H-benzo[b][1,4]oxazin3(4H)-one (2a) [5], 2-(3-chloropropyl)-4-methyl-1,2,4-triazine-3,5(2H,4H)-dione (3a) [21], 2-(4chlorobutyl)-4-methyl-1,2,4-triazine-3,5(2H,4H)-dione (3b) [21], 7-(3-chloropropoxy)-4-methyl2H-chromen-2-one (4a) [5], 7-(4-chlorobutoxy)-4-methyl-2H-chromen-2-one (4b). [5], 5'-fluoro-2'(piperazin-1-yl)-[1,1'-biphenyl]-4-carbonitrile (5) [18], 1-(5-fluoro-4'-methoxy-[1,1'-biphenyl]-2yl)piperazine (6) [18], 2-(piperazin-1-yl)-3,4'-bipyridine (7) [22].

\subsection{Synthesis}

6-(4-Chlorobutoxy)-2-methyl-2H-benzo[b][1,4]oxazin-3(4H)-one (2b). To a suspension of $\mathrm{NaH}$ $(0.11 \mathrm{~g}, 4.47 \mathrm{mmol})$ in anhydrous DMF (3 mL), 6-hydroxy-2-methyl-2H-benzo[b][1,4]oxazin3(4H)-one (1) $(0.61 \mathrm{~g}, 3.43 \mathrm{mmol})$ was added portionwise. The mixture was stirred at room temperature for $10 \mathrm{~min}$, then a solution of the appropriate 1 -bromo-4-chlorobutane $(0.70 \mathrm{~g}$, $4.47 \mathrm{mmol})$ in the same solvent $(2 \mathrm{~mL})$ was added. The reaction mixture was stirred at room temperature for $12 \mathrm{~h}$, poured on ice water and extracted with $\operatorname{AcOEt}(3 \times 20 \mathrm{~mL})$. The organic layers were collected, washed with brine, dried over $\mathrm{Na}_{2} \mathrm{SO}_{4}$ and concentrated under reduced pressure. The crude was purified on a silica gel column by gradient elution from $n$-hexane/AcOEt 7:3 to $n$-hexane/AcOEt, 1:1, to obtain the pure compound as a yellow solid (0.31 g, 36\% yield). ${ }^{1} \mathrm{H}$ NMR $\left(\mathrm{CDCl}_{3}\right): \delta 1.56(\mathrm{~d}, 3 \mathrm{H}, J=6.8 \mathrm{~Hz}), 1.95$ (qn, $\left.2 \mathrm{H}, J=6.0 \mathrm{~Hz}\right), 2.21$ (qn, $2 \mathrm{H}, J=6.0 \mathrm{~Hz}), 3.43(\mathrm{t}, 2 \mathrm{H}, J=6.4 \mathrm{~Hz}), 3.73(\mathrm{t}, 2 \mathrm{H}, J=6.4 \mathrm{~Hz}), 4.59(\mathrm{q}, 1 \mathrm{H}, J=6.8 \mathrm{~Hz}), 6.37$ $(\mathrm{d}, 1 \mathrm{H}, J=2.5 \mathrm{~Hz}), 6.52(\mathrm{dd}, 1 \mathrm{H}, J=2.9$ and $8.8 \mathrm{~Hz}), 6.89(\mathrm{~d}, 1 \mathrm{H}, J=8.8 \mathrm{~Hz}), 8.14\left(\mathrm{~s}, 1 \mathrm{H}, \mathrm{D}_{2} \mathrm{O}\right.$ exchanged). GC/MS m/z $271\left(\mathrm{M}^{+}+2,20\right), 269\left(\mathrm{M}^{+}, 60\right), 179$ (100), 1336 (65), 55 (50).

General Procedure for the Preparation of the Final Compounds $\mathbf{8 a}, \mathbf{b}-\mathbf{1 2} \mathbf{a}, \mathbf{b}$

A stirred mixture of the alkylating agent $\mathbf{2} \mathbf{a}, \mathbf{b}-\mathbf{4} \mathbf{a}, \mathbf{b}(0.9 \mathrm{mmol})$, the piperazine $\mathbf{6}-\mathbf{7}$ $(1.08 \mathrm{mmol})$ and $\mathrm{K}_{2} \mathrm{CO}_{3}(0.15 \mathrm{~g}, 1.08 \mathrm{mmol})$ in acetonitrile $(20 \mathrm{~mL})$ was refluxed overnight. After cooling, the mixture was evaporated to dryness and $\mathrm{H}_{2} \mathrm{O}(20 \mathrm{~mL})$ was added to the residue. The aqueous phase was extracted with AcOEt $(3 \times 20 \mathrm{~mL})$. The collected organic layers were dried over $\mathrm{Na}_{2} \mathrm{SO}_{4}$ and evaporated under reduced pressure. The crude residue was purified by chromatographic column using $\mathrm{CHCl}_{3} / \mathrm{MeOH}, 19: 1$ to give the pure target compound.

6-(3-(4-([3,4'-Bipyridin]-2-yl)piperazin-1-yl)propoxy)-2-methyl-2H-benzo[b][1,4]oxazin-3(4H)-one (8a). Yellow solid, 41\% yield. ${ }^{1} \mathrm{H}$ NMR $\left(\mathrm{CDCl}_{3}\right)$ : $\delta 1.55(\mathrm{~d}, 3 \mathrm{H}, J=6.4 \mathrm{~Hz}), 1.89-1.93(\mathrm{~m}, 2 \mathrm{H})$, 2.42 (br s, 4H), 2.48-2.53 (m, 2H), 3.13 (br s, 4H), $3.92(\mathrm{t}, 2 \mathrm{H}, J=6.4 \mathrm{~Hz}), 4.53-4.60(\mathrm{~m}, 1 \mathrm{H}), 6.33$ $(\mathrm{d}, 1 \mathrm{H}, J=2.3 \mathrm{~Hz}), 6.47(\mathrm{dd}, 1 \mathrm{H}, J=2.3 \mathrm{~Hz}$ and $8.8 \mathrm{~Hz}), 6.86(\mathrm{~d}, 1 \mathrm{H}, J=8.8 \mathrm{~Hz}), 6.95(\mathrm{dd}, 1 \mathrm{H}$, $J=4.7 \mathrm{~Hz}$ and $7.6 \mathrm{~Hz}), 7.47(\mathrm{dd}, 1 \mathrm{H}, J=1.8 \mathrm{~Hz}$ and $7.6 \mathrm{~Hz}), 7.55(\mathrm{~d}, 2 \mathrm{H}, J=5.9 \mathrm{~Hz}), 8.17(\mathrm{br}$ $\mathrm{s}, 1 \mathrm{H}), 8.27(\mathrm{dd}, 1 \mathrm{H}, J=1.8 \mathrm{~Hz}$ and $4.7 \mathrm{~Hz}), 8.65(\mathrm{~d}, 2 \mathrm{H}, J=4.68 \mathrm{~Hz})$. HRMS $\left(\mathrm{ESI}^{+}\right)$calcd for $\left[\left(\mathrm{C}_{26} \mathrm{H}_{29} \mathrm{~N}_{5} \mathrm{O}_{3}\right)+\mathrm{Na}\right]^{+}: 482.2163$, found: 482.2169 . ESI ${ }^{+} / \mathrm{MS} m / z 482\left(\mathrm{M}^{+}\right) . \mathrm{ESI}^{+} / \mathrm{MS} / \mathrm{MS} m / z$ 482 (100); $\mathrm{Mp} 179-180{ }^{\circ} \mathrm{C}$ (from $\mathrm{CHCl}_{3} / n$-hexane).

6-(4-(4-([3,4'-Bipyridin]-2-yl)piperazin-1-yl)butoxy)-2-methyl-2H-benzo[b][1,4]oxazin-3(4H)one (8b). Yellow solid, 33\% yield. ${ }^{1} \mathrm{H} \mathrm{NMR}\left(\mathrm{CDCl}_{3}\right): \delta 1.55(\mathrm{~d}, 3 \mathrm{H}, J=7.0 \mathrm{~Hz}), 1.60-1.67$ $(\mathrm{m}, 2 \mathrm{H}), 1.71-1.80(\mathrm{~m}, 2 \mathrm{H}), 2.36-2.41(\mathrm{~m}, 6 \mathrm{H}), 3.11-3.14(\mathrm{~m}, 4 \mathrm{H}), 3.89(\mathrm{t}, 2 \mathrm{H}, J=6.4 \mathrm{~Hz})$, $4.57(\mathrm{q}, 1 \mathrm{H}, J=6.4 \mathrm{~Hz}), 6.32(\mathrm{~d}, 1 \mathrm{H}, J=2.3 \mathrm{~Hz}), 6.47(\mathrm{dd}, 1 \mathrm{H}, J=2.9 \mathrm{~Hz}$ and $8.8 \mathrm{~Hz}), 6.87$ $(\mathrm{d}, 1 \mathrm{H}, J=8.8 \mathrm{~Hz}), 6.95(\mathrm{dd}, 1 \mathrm{H}, J=7.0 \mathrm{~Hz}$ and $7.61 \mathrm{~Hz}), 7.47(\mathrm{dd}, 1 \mathrm{H}, J=1.8 \mathrm{~Hz}$ and $7.6 \mathrm{~Hz}), 7.54-7.57(\mathrm{~m}, 2 \mathrm{H}), 8.11$ (br s, 1H), $8.27(\mathrm{dd}, 1 \mathrm{H}, J=1.8 \mathrm{~Hz}$ and $4.7 \mathrm{~Hz}), 8.65$ (d, $2 \mathrm{H}, J=5.9 \mathrm{~Hz})$. HRMS $\left(\mathrm{ESI}^{+}\right)$calcd for $\left[\left(\mathrm{C}_{27} \mathrm{H}_{31} \mathrm{~N}_{5} \mathrm{O}_{3}\right)+\mathrm{Na}\right]^{+}: 496.2319$, found: 496.2319 . $\mathrm{ESI}^{+} / \mathrm{MS} m / z 496(\mathrm{M}+\mathrm{Na})^{+} . \mathrm{ESI}^{-} / \mathrm{MS} / \mathrm{MS}$ m/z 496 (100), 295 (66), 226 (56). Mp 174-175 ${ }^{\circ} \mathrm{C}$ (from $\mathrm{CHCl}_{3} / n$-hexane).

2-(3-(4-(5-Fluoro-4'-methoxy-[1,1'-biphenyl]-2-yl)piperazin-1-yl)propyl)-4-methyl-1,2,4-triazine3,5(2H,4H)-dione (9a). Yellow oil, 17\% yield. ${ }^{1} \mathrm{H}$ NMR $\left(\mathrm{CDCl}_{3}\right): \delta 1.68-1.80(\mathrm{~m}, 2 \mathrm{H}), 2.31-2.35$ (m, 6H), 2.77-2.80 (m, 4H), $3.32(\mathrm{~s}, 3 \mathrm{H}), 3.82(\mathrm{~s}, 3 \mathrm{H}), 3.97(\mathrm{t}, 2 \mathrm{H}, J=7.0 \mathrm{~Hz}), 6.90-6.98(\mathrm{~m}, 5 \mathrm{H})$, $7.37(\mathrm{~s}, 1 \mathrm{H}), 7.54-7.56(\mathrm{~m}, 2 \mathrm{H})$. HRMS $\left(\mathrm{ESI}^{+}\right)$calcd for $\left[\left(\mathrm{C}_{24} \mathrm{H}_{28} \mathrm{FN}_{5} \mathrm{O}_{3}\right)+\mathrm{Na}\right]^{+}:$476.2068, found: 476.2068. $\mathrm{ESI}^{+} / \mathrm{MS} m / z 476(\mathrm{M}+\mathrm{Na})^{+}$. $\mathrm{ESI}^{+} / \mathrm{MS} / \mathrm{MS}$ m/z 476 (100).

2-(4-(4-(5-Fluoro-4'-methoxy-[1,1'-biphenyl]-2-yl)piperazin-1-yl)butyl)-4-methyl-1,2,4-triazine3,5(2H,4H)-dione (9b). Dark brown oil, 24\% yield. ${ }^{1} \mathrm{H} \mathrm{NMR}\left(\mathrm{CDCl}_{3}\right): \delta 1.49-1.54(\mathrm{~m}, 2 \mathrm{H})$, 
1.67-1.80 (m, 2H), 2.31-2.36 (m, 6H), 2.77-2.80 (m, 4H), $3.32(\mathrm{~s}, 3 \mathrm{H}), 3.85(\mathrm{~s}, 3 \mathrm{H}), 3.97(\mathrm{t}$ $2 \mathrm{H}, J=7.0 \mathrm{~Hz}), 6.90-6.98(\mathrm{~m}, 5 \mathrm{H}), 7.37(\mathrm{~s}, 1 \mathrm{H}), 7.54-7.56(\mathrm{~m}, 2 \mathrm{H})$. HRMS $\left(\mathrm{ESI}^{+}\right)$calcd for $\left[\left(\mathrm{C}_{25} \mathrm{H}_{30} \mathrm{FN}_{5} \mathrm{O}_{3}\right)+\mathrm{Na}\right]^{+}: 490.2225$, found: 490.2210 . $\mathrm{ESI}^{+} / \mathrm{MS} m / z 490(\mathrm{M}+\mathrm{Na})^{+}$. ESI ${ }^{+} / \mathrm{MS} / \mathrm{MS}$ $m / z 341$ (14).

5'-Fluoro-2'-(4-(3-(4-methyl-3,5-dioxo-4,5-dihydro-1,2,4-triazin-2(3H)-yl)propyl)piperazin-1yl)-[1,1'-biphenyl]-4-carbonitrile (10a). Yellow oil, 51\% yield. ${ }^{1} \mathrm{H} \mathrm{NMR}\left(\mathrm{CDCl}_{3}\right): \delta 1.83-$ $1.93(\mathrm{~m}, 2 \mathrm{H}), 2.29$ (br s, 4H), 2.36-2.40 (m, 2H), 2.71(app t, 4H), $3.31(\mathrm{~s}, 3 \mathrm{H}), 4.02(\mathrm{t}, 2 \mathrm{H}$, $J=7.0 \mathrm{~Hz}), 6.926 .95(\mathrm{~m}, 1 \mathrm{H}), 7.00-7.06(\mathrm{~m}, 2 \mathrm{H}), 7.36(\mathrm{~s}, 1 \mathrm{H}), 7.66-7.76(\mathrm{~m}, 4 \mathrm{H}) . \mathrm{HRMS}\left(\mathrm{ESI}^{+}\right)$ calcd for $\left[\left(\mathrm{C}_{24} \mathrm{H}_{25} \mathrm{FN}_{6} \mathrm{O}_{2}\right)+\mathrm{Na}\right]^{+}: 471.1915$, found: 471.1888. $\mathrm{ESI}^{+} / \mathrm{MS} \mathrm{m} / z 471(\mathrm{M}+\mathrm{Na})^{+}$. $\mathrm{ESI}^{+} / \mathrm{MS} / \mathrm{MS} m / z 471$ (100), 316 (53).

5'-Fluoro-2'-(4-(4-(4-methyl-3,5-dioxo-4,5-dihydro-1,2,4-triazin-2(3H)-yl)butyl)piperazin-1yl)-[1,1'-biphenyl]-4-carbonitrile (10b). Brown oil, $48 \%$ yield. ${ }^{1} \mathrm{H}$ NMR $\left(\mathrm{CDCl}_{3}\right): \delta 1.44-1.53$ $(\mathrm{m}, 2 \mathrm{H}), 1.71-1.81(\mathrm{~m}, 2 \mathrm{H}), 2.30-2.35(\mathrm{~m}, 6 \mathrm{H}), 2.75-2.78(\mathrm{~m}, 4 \mathrm{H}), 3.31(\mathrm{~s}, 3 \mathrm{H}), 3.97(\mathrm{t}, 2 \mathrm{H}$, $J=7.0 \mathrm{~Hz}), 6.926 .98(\mathrm{~m}, 1 \mathrm{H}), 7.00-7.06(\mathrm{~m}, 2 \mathrm{H}), 7.37(\mathrm{~s}, 1 \mathrm{H}), 7.66-7.74(\mathrm{~m}, 4 \mathrm{H}) . \mathrm{HRMS}\left(\mathrm{ESI}^{+}\right)$ calcd for $\left[\left(\mathrm{C}_{25} \mathrm{H}_{27} \mathrm{FN}_{6} \mathrm{O}_{2}\right)+\mathrm{Na}\right]^{+}$: 485.2072, found: 485.2058. $\mathrm{ESI}^{+} / \mathrm{MS} m / z 485(\mathrm{M}+\mathrm{Na})^{+}$. $\mathrm{ESI}^{+} / \mathrm{MS} / \mathrm{MS} m / z 336(100)$.

2-(3-(4-([3,4'-Bipyridin]-2-yl)piperazin-1-yl)propyl)-4-methyl-1,2,4-triazine-3,5(2H,4H)-dione (11a). Yellow oil, 29\% yield. ${ }^{1} \mathrm{H}$ NMR $\left(\mathrm{CDCl}_{3}\right): \delta 1.84-1.92(\mathrm{~m}, 2 \mathrm{H}), 2.34-2.38(\mathrm{~m}, 4 \mathrm{H}), 2.40(\mathrm{t}$, $2 \mathrm{H}, J=7.0 \mathrm{~Hz}), 3.06(\operatorname{app~t}, 4 \mathrm{H}), 3.31(\mathrm{~s}, 3 \mathrm{H}), 4.03(\mathrm{t}, 2 \mathrm{H}, J=6.4 \mathrm{~Hz}), 6.93(\mathrm{dd}, 1 \mathrm{H}, J=7.0 \mathrm{~Hz}$ and $7.6 \mathrm{~Hz}), 7.35(\mathrm{~s}, 1 \mathrm{H}), 7.46(\mathrm{dd}, 1 \mathrm{H}, J=1.8$ and 7.6$), 7.51(\mathrm{dd}, 2 \mathrm{H}, J=1.8 \mathrm{~Hz}$ and $4.7 \mathrm{~Hz})$, $8.25(\mathrm{dd}, 1 \mathrm{H}, J=1.8 \mathrm{~Hz}$ and $4.7 \mathrm{~Hz}), 8.63(\mathrm{~d}, 2 \mathrm{H}, J=5.9 \mathrm{~Hz})$. HRMS $\left(\mathrm{ESI}^{+}\right)$calcd for $\left[\left(\mathrm{C}_{21} \mathrm{H}_{25} \mathrm{~N}_{7} \mathrm{O}_{3}\right)+\mathrm{Na}\right]^{+}:$430.1962, found: 430.1960. $\mathrm{ESI}^{+} / \mathrm{MS} m / z 430(\mathrm{M}+\mathrm{Na})^{+} . \mathrm{ESI}^{+} / \mathrm{MS} / \mathrm{MS}$ $m / z 430(100), 64(26)$.

2-(4-(4-([3,4'-Bipyridin]-2-yl)piperazin-1-yl)butyl)-4-methyl-1,2,4-triazine-3,5(2H,4H)-dione (11b). Brown solid, 10\% yield. ${ }^{1} \mathrm{H}$ NMR $\left(\mathrm{CDCl}_{3}\right): \delta 1.50-1.52(\mathrm{~m}, 2 \mathrm{H}), 1.70-1.78(\mathrm{~m}, 2 \mathrm{H})$, 2.33-2.38 (m, 6H), 3.30-3.32 (m, 4H), $3.31(\mathrm{~s}, 3 \mathrm{H}), 3.97(\mathrm{t}, 2 \mathrm{H}, J=7.0 \mathrm{~Hz}), 6.93(\mathrm{dd}, 1 \mathrm{H}$, $J=7.0 \mathrm{~Hz}$ and $7.6 \mathrm{~Hz}), 7.37(\mathrm{~s}, 1 \mathrm{H}), 7.45-7.48(\mathrm{~m}, 1 \mathrm{H}), 7.51-7.56(\mathrm{~m}, 2 \mathrm{H}), 8.26-8.29(\mathrm{~m}, 1 \mathrm{H})$, 8.63-8.68 (m, 2H). HRMS $\left(\mathrm{ESI}^{+}\right)$calcd for $\left[\left(\mathrm{C}_{22} \mathrm{H}_{27} \mathrm{~N}_{7} \mathrm{O}_{2}\right)+\mathrm{Na}\right]^{+}: 444.2118$, found: 444.2111 . $\mathrm{ESI}^{+} / \mathrm{MS} m / z 444(\mathrm{M}+\mathrm{Na})^{+} . \mathrm{ESI}^{+} / \mathrm{MS} / \mathrm{MS} m / z 444$ (100), 226 (46). Mp 165-167 ${ }^{\circ} \mathrm{C}$ (from $\mathrm{CHCl}_{3} / n$-hexane).

7-(3-(4-([3,4'-Bipyridin]-2-yl)piperazin-1-yl)propoxy)-4-methyl-2H-chromen-2-one (12a). Yellow oil, 41\% yield. ${ }^{1} \mathrm{H}$ NMR $\left(\mathrm{CDCl}_{3}\right): \delta 1.92-2.01(\mathrm{~m}, 2 \mathrm{H}), 2.38(\mathrm{~s}, 3 \mathrm{H}), 2.39($ app t, 4H), 2.51 $(\mathrm{t}, 2 \mathrm{H}, J=7.61 \mathrm{~Hz}), 3.13(\mathrm{app} \mathrm{t}, 4 \mathrm{H}), 4.06(\mathrm{t}, 2 \mathrm{H}, J=5.9 \mathrm{~Hz}), 6.12(\mathrm{~s}, 1 \mathrm{H}), 6.80-6.84(\mathrm{~m}, 2 \mathrm{H})$, $6.96(\mathrm{dd}, 1 \mathrm{H}, J=5.3 \mathrm{~Hz}$ and $7.6 \mathrm{~Hz}), 7.45-7.48(\mathrm{~m}, 2 \mathrm{H}), 7.53-7.6(\mathrm{~m}, 2 \mathrm{H}), 8.26(\mathrm{dd}, 1 \mathrm{H}, J=1.8$ $\mathrm{Hz}$ and $4.7 \mathrm{~Hz}), 8.64-8.66(\mathrm{~m}, 2 \mathrm{H})$. HRMS $\left(\mathrm{ESI}^{+}\right)$calcd for $\left[\left(\mathrm{C}_{27} \mathrm{H}_{28} \mathrm{~N}_{4} \mathrm{O}_{3}\right)+\mathrm{Na}\right]^{+}: 479.2054$, found: 479.2052. $\mathrm{ESI}^{+} / \mathrm{MS} m / z 479(\mathrm{M}+\mathrm{Na})^{+}$. $\mathrm{ESI}^{+} / \mathrm{MS} / \mathrm{MS} m / z 479$ (100), 281 (55), 84 (23).

7-(4-(4-([3,4'-Bipyridin]-2-yl)piperazin-1-yl)butoxy)-4-methyl-2H-chromen-2-one (12b). Yellow oil, $18 \%$ yield. ${ }^{1} \mathrm{H}$ NMR $\left(\mathrm{CDCl}_{3}\right): \delta 1.62-1.69(\mathrm{~m}, 2 \mathrm{H}), 1.80-1.86(\mathrm{~m}, 2 \mathrm{H}), 2.39(\mathrm{~s}, 3 \mathrm{H})$, $2.40-2.43(\mathrm{~m}, 4 \mathrm{H}), 3.13(\mathrm{t}, 2 \mathrm{H}, J=5.4 \mathrm{~Hz}), 3.14-3.19(\mathrm{~m}, 4 \mathrm{H}), 4.02(\mathrm{t}, 2 \mathrm{H}, J=6.9 \mathrm{~Hz}), 6.12(\mathrm{~s}$, $1 \mathrm{H}), 6.78(\mathrm{~d}, 1 \mathrm{H}, J=2.4 \mathrm{~Hz}), 6.83(\mathrm{dd}, 1 \mathrm{H}, J=2.4 \mathrm{~Hz}$ and $8.8 \mathrm{~Hz}), 6.93(\mathrm{dd}, 1 \mathrm{H}, J=4.9 \mathrm{~Hz}$ and $7.3 \mathrm{~Hz}), 7.46-7.48(\mathrm{~m}, 2 \mathrm{H}), 7.53-7.55(\mathrm{~m}, 2 \mathrm{H}), 8.28(\mathrm{dd}, 1 \mathrm{H}, J=4.9 \mathrm{~Hz}$ and $9.3 \mathrm{~Hz}), 8.65$ $(\mathrm{d}, 1 \mathrm{H}, J=5.9 \mathrm{~Hz}), 8.67(\mathrm{~d}, 1 \mathrm{H}, J=5.9 \mathrm{~Hz})$. HRMS $\left(\mathrm{ESI}^{+}\right)$calcd for $\left[\left(\mathrm{C}_{28} \mathrm{H}_{30} \mathrm{~N}_{4} \mathrm{O}_{3}\right)+\mathrm{Na}\right]^{+}$: 493.2210, found: 493.2214. $\mathrm{ESI}^{+} / \mathrm{MS}$ m/z 493 (M+Na) ${ }^{+} \mathrm{ESI}^{+} / \mathrm{MS} / \mathrm{MS}$ m/z 295 (100), 226 (90).

\subsection{Radioligand Binding Assays}

\subsubsection{5- $\mathrm{HT}_{1 \mathrm{~A}}$ Receptor}

The affinity of the compounds for serotonin $5-\mathrm{HT}_{1 \mathrm{~A}}$ receptor was evaluated in membrane preparations from HEK293 cells stably expressing the human cloned receptor, following previously described procedures [23] with minor modifications. Competition binding experiments were performed using $1 \mathrm{nM} \mathrm{[3} \mathrm{H}]-8$-Hydroxy-DPAT $(1 \mathrm{mCi} / \mathrm{mL}$, PerkinElmer NET929250UC) as radioligand. Nonspecific binding was assessed in the presence of $10 \mu \mathrm{M}$ serotonin. 5-Carboxamidotryptamine (5-CT) was included in the assays as reference compound. Assays were carried out in duplicate in 96-well assay plates, in assay buffer ( $50 \mathrm{mM}$ Tris- $\mathrm{HCl}, 5 \mathrm{mM} \mathrm{MgSO}_{4}, \mathrm{pH}=7.4$ ). Assay mixtures were incubated at $37^{\circ} \mathrm{C}$ for $120 \mathrm{~min}$, 
followed by filtration through GF/C glass filter plates, and washed with ice-cold wash buffer $(50 \mathrm{mM}$ Tris- $\mathrm{HCl}, \mathrm{pH}=7.4)$. Competition binding curves, typically constructed with six different concentrations of the compounds, were fitted to a one-site competition model using Prism 6 software (GraphPad, San Diego, CA, USA), and equilibrium dissociation constant $\left(K_{\mathrm{i}}\right)$ of the compounds was calculated according to the Cheng-Prusoff equation. $K_{\mathrm{i}}$ value of the reference ligand 5-CT was $0.32 \pm 0.02 \mathrm{nM}$.

\subsubsection{5- $\mathrm{HT}_{2 \mathrm{~A}}$ Receptor}

The affinity of the compounds for serotonin $5-\mathrm{HT}_{2 \mathrm{~A}}$ receptor was evaluated in membrane preparations from $\mathrm{CHO}-\mathrm{K} 1$ cells stably expressing the human cloned receptor, following previously described procedures [23] with minor modifications. Competition binding experiments were performed using $1 \mathrm{nM}\left[{ }^{3} \mathrm{H}\right]$-ketanserin $(50.3 \mathrm{Ci} / \mathrm{mmol}, 1 \mathrm{mCi} / \mathrm{mL}$, PerkinElmer NET791250UC) as radioligand. Nonspecific binding was assessed in the presence of $1 \mu \mathrm{M}$ methysergide. Risperidone was included in the assays as reference compound. Assays were carried out in duplicate in 96-well assay plates, in assay buffer (50 mM Tris- $\mathrm{HCl}, \mathrm{pH}=7.4$ ). Assay mixtures were incubated at $37^{\circ} \mathrm{C}$ for $30 \mathrm{~min}$, followed by filtration through GF/B glass filter plates, and wash with ice-cold wash buffer ( $50 \mathrm{mM}$ Tris- $\mathrm{HCl}, \mathrm{pH}=6.6$ ). Affinity (equilibrium dissociation constant, $K_{\mathrm{i}}$ ) of the compounds was calculated from competition binding curves as indicated above. $K_{\mathrm{i}}$ value of the reference ligand risperidone was $0.20 \pm 0.04 \mathrm{nM}$.

\subsubsection{5-HT 7 Receptor}

The affinity of the compounds for serotonin $5-\mathrm{HT}_{7}$ receptor was evaluated in membrane preparations from HEK293 cells stably expressing the human cloned 5-HT $7 \mathrm{~A}$ receptor, following previously described procedures [24] with minor modifications. Competition binding experiments were performed using $\left.2 \mathrm{nM} \mathrm{[}{ }^{3} \mathrm{H}\right]-\mathrm{SB} 269970(34.5 \mathrm{Ci} / \mathrm{mmol}$, $0.25 \mathrm{mCi} / \mathrm{mL}$, Perkin Elmer NET1198U250UC) as radioligand. Nonspecific binding was assessed in the presence of $25 \mu \mathrm{M}$ clozapine. Methiothepine was included in the assays as reference compound. Assays were carried out in duplicate in 96-well assay plates, in assay buffer (50 mM Tris- $\mathrm{HCl}, 4 \mathrm{mM} \mathrm{MgCl} 2,1 \mathrm{mM}$ ascorbic acid, $0.1 \mathrm{mM}$ pargyline, $\mathrm{pH}=7.4$ ). Assay mixtures were incubated at $37^{\circ} \mathrm{C}$ for $60 \mathrm{~min}$, followed by filtration through GF/C glass filter plates, and washing with ice-cold assay buffer. Affinity (equilibrium dissociation constant, $K_{\mathrm{i}}$ ) of the compounds was calculated from competition binding curves as indicated above. $K_{\mathrm{i}}$ value of the reference ligand methiothepin was $1.33 \pm 0.32 \mathrm{nM}$.

\subsubsection{Dopamine Receptors}

Competition binding experiments at dopamine $\mathrm{D}_{2 s}$ and $\mathrm{D}_{3}$ receptor were performed to determine the affinity of the compounds. Cell culture conditions are described in Frank et al. [25]. Membrane preparations of transfected CHO-K1 cells stably expressing the human $\mathrm{D}_{2 \mathrm{~s}}$ or $\mathrm{D}_{3}$ receptor were performed according to Bautista-Aguilera et al. [26]. The competition binding experiments were conducted as previously reported $[26,27]$. Briefly, membrane fractions ( $\left.D_{2 s} R: 25 \mu \mathrm{g} / 200 \mu \mathrm{L} ; \mathrm{D}_{3} \mathrm{R}: 20 \mu \mathrm{g} / 200 \mu \mathrm{L}\right)$ were incubated with $\left[{ }^{3} \mathrm{H}\right]$ spiperone $(0.2 \mathrm{nM})$ and test compound for $120 \mathrm{~min}$ at room temperature. Seven appropriate concentrations of compound between $100 \mu \mathrm{M}$ and $0.01 \mathrm{nM}$ were used. Nonspecific binding was determined in the presence of $10 \mu \mathrm{M}$ haloperidol. Haloperidol was also used as reference compound. Separation of the bound ligand from the free ligand was conducted by filtration through GF/B filters using deionized water.

The affinity for dopamine $D_{1}$ and $D_{5}$ receptors was evaluated in membrane fractions of HEK-293 cells stably expressing the human dopamine $\mathrm{D}_{1}$ or $\mathrm{D}_{5}$ receptor. HEK-293- $\mathrm{D}_{1}$ cells were cultured in DMEM/F12 (15 mM HEPES, $\left.1.2 \mathrm{~g} / \mathrm{L} \mathrm{NaHCO}_{3}\right)$ with $10 \%(v / v)$ FBS and $1 \%(v / v)$ L-glutamine. HEK-293-D 5 cells were cultured in DMEM/F12 (with L-glutamine, $\left.1.2 \mathrm{~g} / \mathrm{L} \mathrm{NaHCO}_{3}\right)$ with $20 \%(v / v)$ FBS. Preparation of membrane fractions and radioligand competition assays were performed as previously described [26]. Briefly, membrane fractions were co-incubated with $\left[{ }^{3} \mathrm{H}\right]-\mathrm{SCH} 23390(0.3 \mathrm{nM})$ and different concentrations 
of test compound for $120 \mathrm{~min}$ at room temperature. Fluphenazine $(100 \mu \mathrm{M})$ was used to determine non-specific binding and as reference compound.

Data of at least three independent experiments in triplicate were analyzed using GraphPad Prism 8.1 (San Diego, CA, USA). Binding curves were fitted to a non-linear regression model (one-site competition). $K_{\mathrm{i}}$ values were calculated from $\mathrm{IC}_{50}$ values using the Cheng-Prusoff equation. The statistical calculations were performed on $-\log \left(K_{\mathrm{i}}\right)$. Results are presented in mean $K_{\mathrm{i}}(\mathrm{nM})$ with $95 \%$ confidence intervals (nM).

\subsection{Docking Studies}

The structures of compounds 8b, 9b, 12a, and 12b were loaded into MOE 2019.0102 (Chemical Computing Group, Montreal, Canada). Subsequently, the protonation state was adjusted to dominant at $\mathrm{pH}=7.0$ and the compounds were subjected to energy minimization. X-ray structures of 5- $\mathrm{HT}_{1 \mathrm{~A}}$ (PDB code: 7E2Z [28]), 5- $\mathrm{HT}_{2 \mathrm{~A}}$ (PDB code: 6WHA [29]), $\mathrm{D}_{1}$ (PDB code: 7JOZ [30]), and $\mathrm{D}_{2}$ (PDB code: 6CM4 [31]) were loaded into MOE 2019.0102 and subjected to "QuickPrep" routine, which includes correction of missing loops, adjustment of protonation state and energy minimization. For docking, the initial placement was performed by setting the central interaction towards the acidic aspartate as essential. Initial scoring of 30 poses was performed using London dG scoring function, while refinement was performed with a rigid receptor, and the five best poses were selected based on GBVI/WSA dG scoring function. The best pose was subjected to energy minimization and inspected manually.

\subsection{Stability Assays in Rat Liver Microsomes}

Test compounds were pre-incubated at $37^{\circ} \mathrm{C}$ with rat liver microsomes (Tebu-Bio, Milan, Italy) $(1.0 \mathrm{mg} / \mathrm{mL}$ microsomal protein) at $10 \mu \mathrm{M}$ final concentration in $100 \mathrm{mM}$ potassium phosphate buffer ( $\mathrm{pH} 7.4$ ) for $10 \mathrm{~min}$. Metabolic reactions were initiated by the addition of the NADPH regenerating system (containing $10 \mathrm{mM}$ NADP, $50 \mathrm{mM}$ glucose-6phosphate, and 10 unit/mL glucose-6-phosphate dehydrogenase, final glucose-6-phosphate dehydrogenase concentration, $1 \mathrm{unit} / \mathrm{mL}$ ). After $30 \mathrm{~min}$ incubation, the reaction mixture was quenched by adding an equal volume of cold acetonitrile containing the internal standard. A test compound incubated with microsomes without NADPH regenerating system was included. Quenched samples were centrifuged at $4500 \mathrm{rpm}$ for $15 \mathrm{~min}$ and the supernatants were injected for quantification analysis. Samples (100 $\mu \mathrm{L})$ were analyzed by using an Agilent 1260 Infinity Binary LC System equipped with a diode array detector (Open Lab software was used to analyze the chromatographic data) and a Phenomenex Gemini C-18 column $(250 \mathrm{~mm} \times 4.6 \mathrm{~mm}, 5 \mu \mathrm{m}$ particle size $)$. The samples were eluted using $\mathrm{CH}_{3} \mathrm{CN} / 20 \mathrm{mM}$ ammonium formate $\mathrm{pH} 5.5(7: 3, v / v)$ as eluent (volumetric flow rate $=1 \mathrm{~mL} / \mathrm{min}$ ). Concentrations were quantified by measuring the area under the peak.

The percentage of the parent compound remaining after a 30-min incubation was calculated according to the equation:

$$
\% \text { of parent compound remaining after } 30 \mathrm{~min}=\mathrm{C}_{\text {parent }} / \mathrm{C}_{\text {control }} \times 100
$$

where $C_{\text {parent }}$ is ligand concentration after incubation with microsome fraction and NADPH regenerating system and $C_{\text {control }}$ is ligand concentration after incubation with microsome fraction only.

\subsection{Evaluation of Cell Viability}

\subsubsection{Cell Culture}

SH-SY5Y neuroblastoma cells (cat. CRL-2266, ATCC) were cultured in a 1:1 mixture of Eagle's Minimum Essential Medium (cat. 15-010-CVR, Corning) and Ham's F12 medium (cat. 10-080-CVR, Corning). This medium was supplemented with 10\% $(v / v)$ Fetal Bovine Serum (cat. 35-079-CV, Corning), 1\% (v/v) Glutamine (cat. ECB3000D, Euro Clone) and 1\% $(v / v)$ Penicillin-Streptomycin (cat.30-002-CI, Corning). Cells were cultivated at $37^{\circ} \mathrm{C}$ with $5 \% \mathrm{CO}_{2}$ at saturated humidity. 


\subsubsection{Cell Viability}

Determination of cell growth was performed using the MTT assay at $48 \mathrm{~h}$. [32] On day $1,25,000$ cells / well were seeded into 96-well plates in a volume of $100 \mu \mathrm{L}$. On day 2, the various drug concentrations $(1 \mu \mathrm{M}-100 \mu \mathrm{M})$ were added. In all the experiments, the various drug-solvents (EtOH, DMSO) were added in each control to evaluate possible solvent cytotoxicity. After the established incubation time with drugs $(48 \mathrm{~h})$, MTT $(0.5 \mathrm{mg} / \mathrm{mL})$ was added to each well, and after $3-4 \mathrm{~h}$ incubation at $37^{\circ} \mathrm{C}$, the supernatant was removed. The formazan crystals were solubilized using $100 \mu \mathrm{L}$ of DMSO/EtOH $(1: 1, v / v)$ and the absorbance values at 570 and $630 \mathrm{~nm}$ were determined on the microplate reader Victor 3 (PerkinElmer Life Sciences, Waltham, MA, USA).

\subsubsection{Evaluation of Cell Viability}

Determination of neuroprotection against $\mathrm{H}_{2} \mathrm{O}_{2}$ was performed using the MTT assay at $24 \mathrm{~h}$. [33] On day 1, 25,000 cells/well were seeded into 96-well plates in a volume of $100 \mu \mathrm{L}$. On day 2 , the cells were pretreated $(3 \mathrm{~h})$ with two drug concentrations $(1 \mu \mathrm{M}$ and $5 \mu \mathrm{M}$ ) before being incubated with $400 \mu \mathrm{M} \mathrm{H}_{2} \mathrm{O}_{2}$ for $24 \mathrm{~h}$. In all the experiments, the various drug-solvents (EtOH, DMSO) were added in each control to evaluate a possible solvent cytotoxicity. After $24 \mathrm{~h}$ incubation, MTT $(0.5 \mathrm{mg} / \mathrm{mL})$ was added to each well, and after 3-4 h incubation at $37^{\circ} \mathrm{C}$, the supernatant was removed. The formazan crystals were solubilized using $100 \mu \mathrm{L}$ of DMSO/EtOH $(1: 1, v / v)$ and the absorbance values at 570 and $630 \mathrm{~nm}$ were determined on the microplate reader Victor 3 from PerkinElmer Life Sciences (Waltham, MA, USA).

\subsubsection{Statistical Analysis}

Data were analyzed by applying the one-way repeated measures analysis of variance, and Bonferroni's multiple comparison test followed as a post hoc test. Results are reported as mean SD of at least two to three independent experiments, performed in triplicate. Statistical significance was accepted at $p<0.05$.

\section{Conclusions}

In the present study, we have described the design, synthesis, and biological evaluation of a set of long-chain arylpiperazine derivatives. The structural modification led to the identification of new compounds displaying an array of affinity for serotonin $5-\mathrm{HT}_{1 \mathrm{~A}}, 5$ $\mathrm{HT}_{2 \mathrm{~A}}, 5-\mathrm{HT}_{7}$ receptors, and dopamine $\mathrm{D}_{2}$ receptor and, in some cases, antioxidant properties. Binding affinity data evidenced that: (i) the nature of the terminal fragment had an impact mostly on the affinity at dopamine $\mathrm{D}_{1}$ - and $\mathrm{D}_{2}$-like receptors; (ii) the length of the linker influenced the affinity at serotonin $5-\mathrm{HT}_{1 \mathrm{~A}}$ receptor; (iii) the nature of the biphenyl-like system linked to the piperazine ring influenced the affinity at serotonin $5-\mathrm{HT}_{2 \mathrm{~A}}$ and $5-\mathrm{HT}_{7}$ receptors. The most interesting compounds were: $12 \mathbf{a}$ that combines an affinity profile compatible with antipsychotic activity (affinity for dopamine $\mathrm{D}_{2}\left(K_{\mathrm{i}}=300 \mathrm{nM}\right)$ and 5$\mathrm{HT}_{2 \mathrm{~A}}\left(K_{\mathrm{i}}=315 \mathrm{nM}\right)$ receptors, accompanied by an affinity for $5-\mathrm{HT}_{1 \mathrm{~A}}\left(K_{\mathrm{i}}=41.5 \mathrm{nM}\right)$ and $5-\mathrm{HT}_{7}\left(K_{\mathrm{i}}=42.5 \mathrm{nM}\right)$ receptors $)$ and antioxidant properties; $9 \mathrm{~b}$ that has an affinity profile compatible for studies in the context of ASD (affinity for serotonin 5- $\mathrm{HT}_{1 \mathrm{~A}}\left(K_{\mathrm{i}}=23.9 \mathrm{nM}\right)$, $5-\mathrm{HT}_{2 \mathrm{~A}},\left(K_{\mathrm{i}}=39.4 \mathrm{nM}\right), 5-\mathrm{HT}_{7}\left(K_{\mathrm{i}}=45.0 \mathrm{nM}\right)$ receptors and selectivity over dopamine $\mathrm{D}_{2}$ receptors) and antioxidant properties. Even though the new compounds showed CNS MultiParameter Optimization score predictive of desirable ADMET properties and cross the blood-brain barrier, they fail to achieve in vitro metabolic stability suitable for studies in vivo. The only exception is compound $\mathbf{9 b}$ that therefore deserves further characterization.

Author Contributions: E.L. and M.L. designed the research. M.M. synthesized the compounds. E.L. and C.A. supervised the synthesis, purification, and characterization of the target of compounds. E.P. performed docking studies. M.C., M.D. and H.S. performed the binding assays. M.N. cytotoxicity assays. E.L. conducted the microsomal stability experiments. M.L., E.L., M.C. and H.S. contributed 
to the writing, review, and revision of the manuscript. All authors have read and agreed to the published version of the manuscript.

Funding: M.C. acknowledges funding by the Spanish Ministry of Science and Innovation, grant number PID2020-119754GB-I00. We thank Rocío Piña Márquez and the USEF screening platform at the University of Santiago de Compostela for their assistance with binding assays.

Institutional Review Board Statement: Not applicable.

Informed Consent Statement: Not applicable.

Data Availability Statement: Not applicable.

Acknowledgments: $\mathrm{CHO}-\mathrm{D}_{2 \mathrm{~s}}$ cells were a kind donation of John Shine (Garvan Institute, Australia). CHO-D 3 cells were donated by Pierre Sokoloff (Centre Paul Broca de l'INSERM, France). HEK-D and HEK-D 5 cells were kindly donated from Jochen Lehmann (University of Jena, Germany). M.D. and H.S. participate in the DFG GRK 2158 "Natural products and natural product analogs against therapy-resistant tumors and microorganism". H.S., M.C., E.L. and M.L. participate to the COST Action 18133 "European Research Network on Signal Transduction-ERNEST".

Conflicts of Interest: The authors declare no conflict of interest.

Sample Availability: Samples of all target compounds are available from E.L. and M.L.

\section{References}

1. Meltzer, H.Y.; Massey, B.W. The role of serotonin receptors in the action of atypical antipsychotic drugs. Curr. Opin. Pharmacol. 2011, 1, 59-67. [CrossRef] [PubMed]

2. Reinhold, J.A.; Mandos, L.A.; Rickels, K.; Lohoff, F.W. Pharmacological treatment of generalized anxiety disorder. Expert Opin. Pharmacother. 2011, 12, 2457-2467. [CrossRef]

3. Perez-Lloret, S.; Rascol, O. Piribedil for the Treatment of Motor and Non-motor Symptoms of Parkinson Disease. CNS Drugs 2016, 30, 703-717. [CrossRef] [PubMed]

4. $\quad$ Bhutani, P.; Joshi, G.; Raja, N.; Bachhav, N.; Rajanna, P.K.; Bhutani, H.; Paul, A.T.; Kumar, R.U.S. FDA Approved Drugs from 2015-June 2020: A Perspective. J. Med. Chem. 2021, 64, 2339-2381. [CrossRef]

5. Lacivita, E.; Niso, M.; Mastromarino, M.; Garcia Silva, A.; Resch, C.; Zeug, A.; Loza, M.I.; Castro, M.; Ponimaskin, E.; Leopoldo, M. Knowledge-Based Design of Long-Chain Arylpiperazine Derivatives Targeting Multiple Serotonin Receptors as Potential Candidates for Treatment of Autism Spectrum Disorder. ACS Chem. Neurosci. 2021, 12, 1313-1327. [CrossRef] [PubMed]

6. Pangrazzi, L.; Balasco, L.; Bozzi, Y. Oxidative Stress and Immune System Dysfunction in Autism Spectrum Disorders. Int. J. Mol. Sci. 2020, 21, 3293. [CrossRef]

7. Miyazaki, I.; Asanuma, M.; Murakami, S.; Takeshima, M.; Torigoe, N.; Kitamura, Y.; Miyoshi, K. Targeting 5-HT(1A) receptors in astrocytes to protect dopaminergic neurons in Parkinsonian models. Neurobiol. Dis. 2013, 59, 244-256. [CrossRef]

8. Yuksel, T.N.; Yayla, M.; Halici, Z.; Cadirci, E.; Polat, B.; Kose, D. Protective effect of 5-HT7 receptor activation against glutamateinduced neurotoxicity in human neuroblastoma SH-SY5Y cells via antioxidative and antiapoptotic pathways. Neurotoxicol. Teratol. 2019, 72, 22-28. [CrossRef]

9. Kaddouri, Y.; Abrigach, F.; Yousfi, E.B.; El Kodadi, M.; Touzani, R. New thiazole, pyridine and pyrazole derivatives as antioxidant candidates: Synthesis, DFT calculations and molecular docking study. Heliyon 2020, 6, e03185. [CrossRef]

10. Kucukkilinc, T.T.; Yanghagh, K.S.; Ayazgok, B.; Roknipour, M.A.; Moghadam, F.H.; Moradi, A.; Emami, S.; Amini, M.; Irannejad, H. Synthesis and neuroprotective activity of novel 1,2,4-triazine derivatives with ethyl acetate moiety against $\mathrm{H}_{2} \mathrm{O}_{2}$ and $\mathrm{A} \beta$-induced neurotoxicity. Med. Chem. Res. 2017, 26, 3057-3071. [CrossRef]

11. Largeron, M.; Mesples, B.; Gressens, P.; Cecchelli, R.; Spedding, M.; Le Ridant, A.; Fleury, M. The neuroprotective activity of 8-alkylamino-1,4-benzoxazine antioxidants. Eur. J. Pharmacol. 2001, 424, 189-194. [CrossRef]

12. Robertson, A.L.; Ogryzko, N.V.; Henry, K.M.; Loynes, C.A.; Foulkes, M.J.; Meloni, M.M.; Wang, X.; Ford, C.; Jackson, M.; Ingham, P.W.; et al. Identification of benzopyrone as a common structural feature in compounds with anti-inflammatory activity in a zebrafish phenotypic screen. Dis. Model Mech. 2016, 9, 621-632. [CrossRef] [PubMed]

13. Okada, M.; Fukuyama, K.; Okubo, R.; Shiroyama, T.; Ueda, Y. Lurasidone Sub-Chronically Activates Serotonergic Transmission via Desensitization of 5-HT1A and 5-HT7 Receptors in Dorsal Raphe Nucleus. Pharmaceuticals 2019, 12, 149. [CrossRef]

14. Rajagopal, L.; Massey, B.W.; Michael, E.; Meltzer, H.Y. Serotonin (5-HT)1A receptor agonism and 5-HT7 receptor antagonism ameliorate the subchronic phencyclidine-induced deficit in executive functioning in mice. Psychopharmacology 2016, 233, 649-660. [CrossRef] [PubMed]

15. Mayol-Llinàs, J.; Nelson, A.; Farnaby, W.; Ayscough, A. Assessing molecular scaffolds for CNS drug discovery. Drug Discov. Today 2017, 22, 965-969. [CrossRef] [PubMed]

16. Kolyasnikova, K.N.; Vichuzhanin, M.V.; Konstantinopol'skii, M.A.; Trofimov, S.S.; Gudasheva, T.A. Synthesis and pharmacological activity of analogs of the endogenous neuropeptide cycloprolylglycine. Pharma. Chem. J. 2012, 46, 96-102. [CrossRef] 
17. Obach, R.S.; Baxter, J.G.; Liston, T.E.; Silber, B.M.; Jones, B.C.; MacIntyre, F.; Rance, D.J.; Wastall, P. The prediction of human pharmacokinetic parameters from preclinical and in vitro metabolism data. J. Pharmacol. Exp. Ther. 1997, 283, 46-58. [PubMed]

18. Lacivita, E.; Podlewska, S.; Speranza, L.; Niso, M.; Satała, G.; Perrone, R.; Perrone-Capano, C.; Bojarski, A.J.; Leopoldo, M. Structural modifications of the serotonin 5-HT7 receptor agonist N-(4-cyanophenylmethyl)-4-(2-biphenyl)-1-piperazinehexanamide (LP-211) to improve in vitro microsomal stability: A case study. Eur. J. Med. Chem. 2016, 120, 363-379. [CrossRef] [PubMed]

19. Daina, A.; Michielin, O.; Zoete, V. SwissADME: A free web tool to evaluate pharmacokinetics, drug-likeness and medicinal chemistry friendliness of small molecules. Sci. Rep. 2017, 7, 42717. [CrossRef]

20. Brown, J.W.; Gangloff, A.R.; Jennings, A.J.; Vu, P.H. Poly (ADP-Ribose) Polymerase (PARP) Inhibitors. International Patent Application No. PCT/US2010/028878, 30 September 2010.

21. Kumar, J.S.; Majo, V.J.; Hsiung, S.C.; Millak, M.S.; Liu, K.P.; Tamir, H.; Prabhakaran, J.; Simpson, N.R.; Van Heertum, R.L.; Mann, J.J.; et al. Synthesis and in vivo validation of [O-methyl-11C]2-\{4-[4-(7-methoxynaphthalen-1-yl)piperazin- 1-yl]butyl\}-4-methyl2H-[1,2,4]triazine-3,5-dione: A novel 5-HT1A receptor agonist positron emission tomography ligand. J. Med. Chem. 2006, 49, 125-134. [CrossRef]

22. Hansen, H.D.; Lacivita, E.; Di Pilato, P.; Herth, M.M.; Lehel, S.; Ettrup, A.; Andersen, V.L.; Dyssegaard, A.; De Giorgio, P.; Perrone, R.; et al. Synthesis, radiolabeling and in vivo evaluation of [(11)C](R)-1-[4-[2-(4-methoxyphenyl)phenyl]piperazin-1-yl]-3-(2pyrazinyloxy)-2-propanol, a potential PET radioligand for the 5-HT(7) receptor. Eur. J. Med. Chem. 2014, 79, 152-163. [CrossRef] [PubMed]

23. Kaczor, A.A.; Silva, A.G.; Loza, M.I.; Kolb, P.; Castro, M.; Poso, A. Structure-Based Virtual Screening for Dopamine D2 Receptor Ligands as Potential Antipsychotics. ChemMedChem 2016, 11, 718-729. [CrossRef] [PubMed]

24. Varin, T.; Gutiérrez-de-Terán, H.; Castro, M.; Brea, J.; Fabis, F.; Dauphin, F.; Aqvist, J.; Lepailleur, A.; Perez, P.; Burgueño, J.; et al. Phe369(7.38) at human 5-HT(7) receptors confers interspecies selectivity to antagonists and partial agonists. Br. J. Pharmacol. 2010, 159, 1069-1081. [CrossRef] [PubMed]

25. Frank, A.; Kiss, D.J.; Keserû, G.M.; Stark, H. Binding kinetics of cariprazine and aripiprazole at the dopamine D3 receptor. Sci. Rep. 2018, 8, 12509. [CrossRef]

26. Bautista-Aguilera, Ó.M.; Hagenow, S.; Palomino-Antolin, A.; Farré-Alins, V.; Ismaili, L.; Joffrin, P.-L.; Jimeno, M.L.; Soukup, O.; Janočková, J.; Kalinowsky, L.; et al. Multitarget-Directed Ligands Combining Cholinesterase and Monoamine Oxidase Inhibition with Histamine $\mathrm{H}_{3} \mathrm{R}$ Antagonism for Neurodegenerative Diseases. Angew. Chem. Int. Ed. 2017, 56, 12765. [CrossRef]

27. Schübler, M.; Sadek, B.; Kottke, T.; Weizel, L.; Stark, H. Synthesis, Molecular Properties Estimations, and Dual Dopamine $\mathrm{D}_{2}$ and $\mathrm{D}_{3}$ Receptor Activities of Benzothiazole-Based Ligands. Front. Chem. 2017, 5, 64. [CrossRef]

28. Xu, P.; Huang, S.; Zhang, H.; Mao, C.; Zhou, X.E.; Cheng, X.; Simon, I.A.; Shen, D.D.; Yen, H.Y.; Robinson, C.V.; et al. Structural insights into the lipid and ligand regulation of serotonin receptors. Nature 2021, 592, 469-473. [CrossRef]

29. Kim, K.; Che, T.; Panova, O.; DiBerto, J.F.; Lyu, J.; Krumm, B.E.; Wacker, D.; Robertson, M.J.; Seven, A.B.; Nichols, D.E.; et al. Structure of a Hallucinogen-Activated Gq-Coupled 5-HT2A Serotonin Receptor. Cell 2020, 182, 1574-1588.e19. [CrossRef]

30. Sun, B.; Feng, D.; Chu, M.L.; Fish, I.; Lovera, S.; Sands, Z.A.; Kelm, S.; Valade, A.; Wood, M.; Ceska, T.; et al. Crystal structure of dopamine $\mathrm{D}_{1}$ receptor in complex with $\mathrm{G}$ protein and a non-catechol agonist. Nat. Commun. 2021, 12, 3305. [CrossRef]

31. Wang, S.; Che, T.; Levit, A.; Shoichet, B.K.; Wacker, D.; Roth, B.L. Structure of the $\mathrm{D}_{2}$ dopamine receptor bound to the atypical antipsychotic drug risperidone. Nature 2018, 555, 269-273. [CrossRef]

32. Pati, M.L.; Hornick, J.R.; Niso, M.; Berardi, F.; Spitzer, D.; Abate, C.; Hawkins, W. Sigma-2 receptor agonist derivatives of 1-Cyclohexyl-4-[3-(5-methoxy-1,2,3,4-tetrahydronaphthalen-1-yl)propyl]piperazine (PB28) induce cell death via mitochondrial superoxide production and caspase activation in pancreatic cancer. BMC Cancer 2017, 17, 51. [CrossRef] [PubMed]

33. Gay, N.H.; Phopin, K.; Suwanjang, W.; Songtawee, N.; Ruankham, W.; Wongchitrat, P.; Prachayasittikul, S.; Prachayasittikul, V. Neuroprotective Effects of Phenolic and Carboxylic Acids on Oxidative Stress-Induced Toxicity in Human Neuroblastoma SH-SY5Y Cells. Neurochem. Res. 2018, 43, 619-636. [CrossRef] [PubMed] 